\title{
Ante Andabak
}

Stvarnost koja ne može bez 'dobre nemogućnosti'. Negativna dijalektika '68.

Kriza i kritike racionalnosti. Nasljeđe '68.

Ur. B. Mikulić/M. Žitko, Zagreb: Filozofski fakultet 2019. 


\section{SAŽETAK}

'Soyez réalistes, demandez l'impossible' jedan je od amblematskih slogana šezdesteosme, a uvriježeno se tumači kao sublimni prikaz stanja u kojem se kao 'nemoguće' označuje svaka alternativa postojećem. Ključne lekcije prve generacije Frankfurtske škole, kritika instrumentalnog uma i ustrajavanje na konstitutivnom statusu nade u kritičkom mišljenju, pomoći će nam pri konceptualizaciji realnog u kojem je traženje i nadanje nemogućem praktička, a nikako puko sanjarska i nedjelotvorna pozicija. Nadalje ćemo na primjeru Spinoze pokazati nužnost inzistiranja na mogućnosti upravo u njenom negativnom, naizgled obeshrabrujućem obliku, a stara Hegelova zamjerka kako mu nedostaje ontološke negativnosti omogućit će nam da razumijemo krucijalnu važnost granice Spinozine filozofije, koja se jasno ocrtava u teorijskom stavu što ga je zauzeo spram uključivanja žena u politički život. Namjera rada je objasniti zašto su filozofska razmatranja daleko od puko tankoćutnih promišljanja bez koristi, ili još gore, zbog svoje kompliciranosti otežavajuća za prikladnu teoretizaciju progresivnih politika. Suprotno tome, upravo zbog kompleksnosti tih ideja one su od nasušne potrebe za preciznijim procjenjivanjem trenutnih emancipatorskih nastojanja. 
Reality that Cannot Do Away with 'Good Impossibility':

The Negative Dialectics of '68

\section{ABSTRACT}

'Soyez réalistes, demandez l'impossible' is one of 1968's emblematic slogans, commonly considered a sublime expression of the situation in which every alternative to the existing socio-economic structure is deemed impossible. This paper will try to show its inherent explanatory potential. Critique of instrumental reason and the insistence on the constitutive role of hope in critical thinking, key lessons by the Frankfurt school's first generation, will help us conceptualise the real in which the demand and hope for the impossible are not only justified, but even practical, instead of being characteristic of a starry-eyed and inefficient position. Furthermore, on the example of Spinoza we will show why insisting on possibility precisely in its negative form, is necessary, and Hegel's old reproach to Spinoza, that he lacks ontological negativity, will allow us to understand the crucial importance of the limit of Spinoza's philosophy, clearly discernible in the theoretical stance he took against the inclusion of women in political life. The aim of the paper is to explain why the philosophical considerations are far from simply being useless, oversensitive ruminations, or even worse, hindering for an appropriate theorisation of progressive politics due to their complexity. In fact, the opposite is the case; it is precisely the complexity of those ideas that is the reason why the ongoing emancipatory struggles are in dire need of them and the precision they can bring. 
'Soyez réalistes, demandez l'impossible!' jedan je od amblematskih slogana i grafita Maja '68. koji možda najbolje predstavlja duh onog vremena. No, za ovaj rad značajnije je što njegov smisao jednako jako rezonira i danas, izvan specifičnog konteksta u kojem je nastao. ${ }^{01}$ Poruka koju poletno prenosi i dalje je conditio sine qua non za bilo koju radikalnu kritiku i smisleni otpor trenutnom socio-ekonomskom stanju. Preko svojih poziva i potraživanja slogan nam daje opis vremena u kojima se (još uvijek) nalazimo, gdje se kao a priori nemoguće, iluzorno i bez doticaja sa stvarnošću odbacuje svako promišljanje, a kamoli tek pokušaj stvaranja društvenog uređenja koji bi uistinu bio alternativa postojećem. Drugačije rečeno, upućuje nas na to da je prihvaćanje naizgled potpuno neostvarivih zahtjeva i ciljeva jedini način da se koncipira djelovanje za alternativu. Tako se zapravo poznata fraza o politici 'kao umijeću mogućeg' izokreće, politika koja stremi za nemogućim postaje jedina vrijedna važnosti i moći koju strukturno posjeduje. Kako je to koncizno sročio Bill Ayers, jedan od studentskih vođa američke kontrakulture iz 1960-ih, pozivajući se na primjer abolicionistâ koji su sve do zadnje minute bili utopisti sa nerealističnim projektom jer se nisu bavili 'mogućim', nego idealima za koje se vrijedi boriti.:

Naš ljudski i društveni razvoj ne bi se dogodio da smo se samo držali umijeća mogućeg. Ako razmišljamo o povijesti ove zemlje, tek onda kad su ljudi zahtijevali nemoguće, išlo se naprijed. ${ }^{02}$

Slogan s jedne strane sadrži pogled na nedvojbeno sumorno stanje u kojem se nalazimo ako želimo stubokom mijenjati stvarnost, a s druge strane lako nas može nagnati na razmišljanje o tolikim nemogućnostima koje su se kroz povijest ipak dogodile i koje nas neminovno tjeraju da se zapitamo, zašto bi i ove suvremene granice, do kojih je

01 Tako primjerice S. Žižek u Demanding the Impossible (2013), 139-144, tvrdi da "the great task of thinking today [is] to redefine and rethink the limits of the possible and the impossible" te nas upozorava na Lacanovu formulu za prevladavanje "ideološke nemogućnosti”. Ona nije "everything is possible but the impossible happens. The Lacanian impossible-real is not an a priori limitation, which needs to be realistically taken into account, but the domain of action."

02 Odgovarajući na pitanje u intervju za portal Truth Out (2016b) zašto je svoju knjigu Demand the Impossible! A Radical Manifesto (2016a) nazvao upravo tako, Ayers pripisuje slogan Che Guevari, ali se pritom ne poziva ni na jedan izvor. 
tobože jedino realno ostvariva društvena emancipacija, bile tako nepomične i finalne.

'Budimo realni, tražimo nemoguće' poslužit će nam dakle kao ulazna točka, ali će pored toga biti i provodna nit rada, niska na koju ćemo nanizati eksplikacije bitnih aspekata u mišljenju radikalne promjene. Pritom treba upozoriti da imperativ prvog lica množine, kakav je uvriježen u prijevodu slogana, odudara od francuskog izvornika u drugom licu množine, pa bi točan prijevod morao glasiti: "Budite realni, tražite nemoguće". Na prijelaz u licu koji se dogodio u prijevodu ne upozoravamo iz puke jezične pedantnosti nego zato jer je pitanje o tome tko izgovara imperativ ujedno i pitanje pripada li subjekt iskaza među nas koji moramo biti realni i tražiti nemoguće ili je izmješten iz tog kolektiva pozicijom autoriteta i gospodara koji nalaže što da se radi, i utoliko od presudnog značaja za promišljanje filozofskih implikacija ovog slogana. Ipak, ovoj specijalnoj problematici nećemo se moći posvetiti, za okvir ovoga rada dovoljno je reći kako ćemo se voditi smislom slogana kakav se nadaje u prijevodnoj inačici- $\mathrm{Bu}$ dimo realni, tražimo nemoguće - koja subjekt iskazivanja imperativa uključuje u njegove adresate.

\section{Snaga slogana}

Počnimo sa kratkim osvrtom na efektnost i pamtljivost našeg slogana. Lako se da primjetiti da je za to zaslužno lirično korištenje paradoksa zbog kojeg nas te pune četiri riječi i ostavljaju sa osjećajem tako tipičnim za poeziju da se s malo riječi uspjelo izraziti nešto mnogo više i dublje. No, detektirati jezičnu figuru i diviti se ekonomičnom izražavanju, što je uostalom nužan uvjet za svaki slogan, nije ni približno dovoljno ako želimo podrobnije shvatiti snagu, kontinuiranu popularnost i značaj ovog našeg.

Na jedan od takvih načina čitanja slogana ukazao je Paul Watzlawick, psihoterapeut, teoretičar komunikacije i utjecajni autor toga doba. ${ }^{03}$ On je naveo slogan kao primjer jezičnih oblika desne hemisfere, tako ih nazvavši oslanjajući se na spoznaje neuroznanosti koje nas uče o relativnoj autonomiji, odnosno lateralizaciji polutki u mozgu. Za njegovu poziciju od presudnog je značaja to što racionalno analiziranje pripada lijevoj, dok konceptualizacija cjeline - pristup realnosti

03 Paul Watzlawick (1978), The Language of Change: Elements of Therapeutic Communication; za relevantna mjesta s obzirom na naše izlaganje, v. str. 3-28; 40-91. 
s obzirom na mentalnu sliku svijeta - pripada desnoj strani mozga. Kako Watzlawick piše iz psihoterapeutske pozicije, on polazi od svojih pacijenata koji najčešće imaju problema baš sa pristupom realnosti u kojoj ne mogu živjeti na zadovoljavajući način. Budući da je razgovor primarni način s kojim se u psihoterapiji pokušavaju otkloniti problemi, on smatra da bi terapeuti trebali govoriti jezikom koji je više obilježen oblicima desne hemisfere. Prateći latinsku izreku s kojom i počinje djelo - similia similibus curantur (Slično se sličnim liječi) - Watzlawick drži da moramo koristiti odgovarajući jezik kako bi ostvarili potrebne promjene te time objašnjava zašto standardne metode racionalnog objašnjavanja, argumentiranja i analiziranja često nisu od dovoljne pomoći u terapiji. Takvi pristupi naprosto ne mogu doprijeti dovoljno snažno do načina na koji konceptualiziramo zbilju, gdje najčešće i leži problem. Jezični oblici desne hemisfere, za čije se korištenje on zalaže, sastoje se od raznih vrsta jezičnih igara i dosjetki, sažimanja, višeznačnosti i proturječja.

Ako prihvatimo takvu perspektivu možemo objasniti snagu slogana time što govori pravim jezikom s obzirom na svoje nakane, a to je drukčija konceptualizacija zbilje. To će o sloganu reći i sam Watzlawick. ${ }^{04}$ Upravo je očigledna proturječnost slogana ono što ga čini posebice uvjerljivim i omogućuje da tako efektno pronosi radikalni pogled na situaciju u kojoj bi realna bila samo promjena koja je potpuna, ali zato nemoguća unutar postojećeg političkog okvira. No, na takav način mogu govoriti i reklame, kako to pokazuju drugi primjeri jezičnih oblika desne hemisfere, tako da sama činjenica da je nešto izraženo u tom jeziku ne znači da je automatski riječ o jeziku promjene, već samo o pamtljivom i dojmljivom izražavanju koji ima puno većeg potencijala da utječe na pacijenta. K tome, u našem slučaju pacijent je čitavo društveno-ekonomsko uređenje tako da bi trebali ostaviti psihoterapeutski prostor u njemu nužnoj intimi i tražiti prikladnije pristupe s kojim bi objasnili snagu slogana. Ali prije nego što to uradimo, iskoristimo još trenutak u tom psihoterapeutskom prostoru da razmislimo o načinima utjecaja i promislimo činjenicu da se naš slogan pojavljuje u imperativnom obliku.

Na prvi pogled, bilo bi suludo da Budimo realni, tražimo nemoguće doživljavamo kao jedan od pravih imperativa kakve koristimo, slušamo ili na koje se oglušujemo u svakodnevnom životu (Ustani! Pogledaj ovamo! Dodaj mi to!). No, kako bi mogli ispunjavati ili izda-

04 Watzlawick (1978), 83. 
vati ikakve naredbe u sklopu organiziranja i provedbe progresivnih politika, moramo prihvatiti ethos našeg slogana, što bi efektivno značilo da postupamo po njegovoj naredbi. U protivnom, do željenog progresivnog djelovanja neće ni doći na nekoj značajnijoj razini, jer ćemo unaprijed otpisati trud koji je potrebno uložiti kao neizbježno uzaludan i uvidjeti da su naša nastojanja, mada plemenita, naprosto himere. Tako mišljen, imperativni oblik slogana nije puko formalno prigodan s obzirom na mjesto njegova historijskog pojavljivanja, nego je i sadržajno opravdan i prijeko potreban.

Korisno je stoga obratiti se Watzlawickovim opaskama o imperativu. Polazeći od primjera hipnoterapije, koja kad god može izbjegava negativne formulacije, on je proširuje općenito na svaki vid instrukcije ili naredbe jer je mnogo efektnija kad je izražena u pozitivnom jeziku, slobodnom od negacija. "Što je jezični izraz naredbe više negativan $i$ zastrašujući, to će onaj drugi biti manje spreman da posluša.” Uz jezik slobodan od negacija vrijedno je spomenuti, kako naglašava Watzlawick, da su funkcije jezika desne hemisfere gotovo identične sa psihoanaltičkim konceptom primarnog procesa, a ta gotova identičnost može nas dovesti do daljnjih, iznimno zanimljivih teorijskih uvida. ${ }^{05}$ No, kako zaista pomiriti naš slogan s navodno instinktivno razumljivim uvidom da je "pozitivna i konkretna formulacija preduvjet za svaki uspješni utjecaj”? ${ }^{06}$ Zar ne bi bilo korisnije da izgubi svoju zastrašujuću notu, bude pozitivan, da proklamira izvedivost određenih potraživanja, a ne da takoreći sam sebi skače u usta? Ne bi li upravo traženje mogućeg trebalo biti jamac realnosti? Ipak, sloganu bi se lišavanjem negativnog oblika mogućnosti urušila ključna figura misli, srozao bi se na nedojmljivu prozaičnost, a šteta u tom slučaju ne bi bila samo stilske naravi. Bez konstitutivne kontradikcije izgubio bi samu logičku potku koja ga i kvalificira da bude među primjerima jezika desne hemisfere. Način mišljenja, koji je potreban da bi se slogan mogao smisleno razumjeti, ne može, kako ćemo u nastavku pokazati, ni bez

05 Naime, primarni proces označava nesvjesne misli kojima upravlja načelo ugode i koje nisu pod stegom realnosti i logike, koje naprosto ne znaju za riječ Ne. Tipičan primjer je san, te iako se u njemu pojavljuje mnoštvo negacija i kontradikcija, ipak, kako nam objašnjava M. Dolar (2012), Hegel or Freud, u snu "[...] negation cannot be isolated, it only exists in the web of substitutions, condensations, and displacements. This web of ubiquitous negativity is paradoxically premised on the elision, the omission of 'no' as a singular marker of negation."

06 Watzlawick, isto, 66. 
imperativnog oblika ni bez proturječja i negativnosti. Dok se neki drugi slogani '68., primjerice Zabranjeno je zabranjivati i Sva moć mašti, veoma dobro mogu objasniti Watzlawickovim pristupom, za Budimo realni, tražimo nemoguće potrebna je nešto drugo - dijalektika. ${ }^{7}$

\section{2. "Tek bi krajnja udaljenost bila blizina"}

Dijalektika se, u ionako izrazito polisemičnom korpusu filozofskih termina, ističe po svojoj mnogoznačnosti. Mi ćemo je ovdje misliti pod njenim vjerovatno najpoznatijim vidom, onim kojeg ugrubo možemo označiti kao hegelijansko-marksistički. ${ }^{08}$ Preciznije, govorit ćemo o varijanti dijalektike koju je iznjedrila kritička teorija, a za nju će nam Theodor Adorno i Herbert Marcuse poslužiti kao vodiči. Tako će Adorno dijalektiku smatrati suštinom Hegelove filozofije koja se "ne može usporediti sa bilo kojim metodičkim ili ontološkim principom koji bi je karakterizirao, slično kao Platona iz srednjeg perioda učenje o idejama ili monadologija Leibniza. Dijalektika ne znači ni postupak duha kojim se ovaj othrvava od vezanosti za svoj objekt — kod njega ona čini doslovce suprotnost, permanentnu konfrontaciju objekta sa svojim vlastitim pojmom - niti nazor na svijet u čije šeme bi se trebalo utisnuti realitet. Tako malo koliko je dijalektika naklonjena pojedinačnoj definiciji, tako malo se ona sama povinuje bilo kakvoj definiciji. Ona je nezbunjivo nastojanje da se spoje kritička svijest uma o sebi samom i kritičko iskustvo predmeta." ${ }^{9}$

Premda smo se za pokazivanje unutarnje logike našeg slogana mogli fokusirati i na druge mislioce, ${ }^{10}$ izbor Adorna i Marcusea od članova Frankfurtske škole može se opravdati iz najmanje tri razloga. Prvi je što su iznimno elegantno i minuciozno koristili dijalektiku i o njoj izravno i naširoko pisali. Drugi je što su ta pisanja objavljena u nekim od najistaknutijih djela 1960-ih, u Čovjeku jedne dimenzije

07 Razliku između tih dvaju misaonih pristupa M. Dolar (2012), eksplicira:

"What could be further from the stringency of the conceptual concatenation in Hegel's Logic, each step inherently linked to the previous by self-reflexive negativity, than the infinite sliding over homonyms, similarities, and slips? The former is determined by a 'no' at every step, the latter ignores 'no' altogether."

08 Za širu raspravu o dijalektici u ovom ključu v. F. Jameson (2009).

09 T. W. Adorno (1972), Tri studije o Hegelu, 17 (prijevod adaptiran).

$10 \mathrm{Za}$ kritiku Adornovog razumijevanja Hegela iz suvremene pozicije lacanovskog čitanja Hegela v. F. Vighi (2012), 35-42. 
(1964) i Negativnoj dijalektici (1966), tako da obojica bez sumnje pripadaju nekolicini najvažnijih intelektualnih izvorišta za tadašnju Novu ljevicu i radikalne studentske pokrete. Treći je razlog njihov znameniti međusobni sukob upravo oko tog studentskog aktivizma čiji su revolucionarni potencijal različito valorizirali. Zbog tog praktičkog mimoilaženja, još interesantnije je pratiti baš taj tandem i njihovu više-manje istovjetnu i međusobno dopunjujuću teorijsku ekspoziciju dijalektike. Ovom sukobu ćemo se obratiti kasnije, prethodno je potrebno posvetiti se problem proturječnosti i negativnosti te pokušati objasniti zašto su prijeko potrebne za izricanje imperativa u sloganu.

Proturječje je, kako važi još od Aristotela, najočigledniji, a često i jako pouzdan znak lošeg zaključivanja i nedosljednog mišljenja. ${ }^{11}$ Logično je da će svaki sustav misli sa veridičkim pretenzijama nastojati spriječiti da mu se dogodi takav krimen kao što su unutarnje kontradikcije. No, što ako kontradikcija nije samo krimen — jednostran znak nedorasle misli koja ne može uspostaviti niti unutarnju koherentnost, nego može biti i upravo obratno, odlika mišljenja koji odgovara samoj prirodi onog što misli? Na to upozorava Marcuse:

Dijalektička logika razumijeva proturječnosti kao "nužnost” pripadnu samoj "prirodi misli" zato što je proturječnost u samoj prirodi objekta misli, u stvarnosti u kojoj je umsko još uvijek neumsko, a iracionalno još uvijek racionalno.[...] Dani realitet ima svoju vlastitu logiku i svoju vlastitu istinu. Napor da se shvate kao takve i transcendiraju pretpostavlja drugačiju logiku, istinu koja proturječi. ${ }^{12}$

Možda možemo bez proturječja u mišljenju shvaćati stvarnost, no, želimo li tu stvarnost mijenjati i nadići, moramo se služiti drukčijom logikom i prigrliti proturječje istine. Da bi mogli proturječiti danom realitetu, prvo ga moramo odbiti u svrhu nečega, negirati radi nečega. Zato negativnost prethodi i uslovljava poziciju s koje ćemo se moći smisleno postaviti antagonistički spram stvarnosti. Adorno se snažno obraća takvoj negativnosti, inzistirajući da iz nje filozofija crpi ono što je uopće još može legitimirati jer će inače kapitulira pred onim nerazrješivim, artikuliranim kroz sentiment da je sve tako-i-nikako-drukčije.

Vrstan primjer koji nam danas plastično dočarava takvo stanje stih je Toma Waitsa: "Laissez-faire mi amour, c'est la vie", koji on pjeva sa svojim znamenitim režećim glasom iz kojeg izbija sva sila

11 Usp. Aristotel, Metafizika, 1006a 20-30.

12 H. Marcuse (1968), Čovjek jedne dimenzije, 139. 
sardoničnosti, a pretpostavka intelektualnosti, koja se često u anglosaksonskom govornom području pridaje onima koji koriste francuske izraze, uzdiže tvrdokornog cinika iz pjesme u mudrog čovjeka koji je vidio svijeta i zna kako on funkcionira. A funkcionira tako da su kretanje i logika kapitala nedodirljivi, pa su zato i smješteni u samo srce života koji je naprosto takav i nema kako biti drukčiji. No, teško da je Waitsov protagonist iz ove pjesme (Everything Goes To Hell) ozlojađeniji i mračnijeg pogleda na svijet od jednog Adorna, ali potonji koristi negativnost na mnogo rigorozniji način. U pogledu sentimenta c'est la vie, Adornova dijalektička negativnost to prokazuje kao "fetiš neopozivosti postojećeg" koji, kako on ističe, "nestaje pred uvidom da nije naprosto tako i nikako drukčije, već da sve nastaje u određenim uvjetima." ${ }^{13}$ Osvijetliti određene uvjete u kojima je nastalo ono što se hipostazira, efektan je način za prokazivanje i pravi put za svrgavanje takvog fetiša. Marx je to uradio služeći se "mrakom evropskog srednjeg vijeka" naspram robinzonijada klasičnih političkih ekonomista koji su kapitalistički način ponašanja upisivali u čovjeka od samog početka historijskog razvoja, kao nepromjenjive ljudske karakteristike prikazujući tako povijesno uvjetovane odnose dominacije kao prirodnu datost. ${ }^{14}$ Naspram takve naturalizacije historijskih procesa, značaj medievalnog mraka je u tome što se u njemu odnosi dominacije bjelodano pojavljuju kao "lične zavisnosti koje čine datu društvenu osnovicu”, pa baš zbog toga ni narav rada ni njegovi proizvodi "nisu prinuđeni da uzimaju fantastična obličja različna od njihove predmetnosti." ${ }^{15}$ Dakako, fantastična obličja su fetiški karakter robe koji omogućava depresonalizirani, naizgled neizravni odnos dominacije svojstven kapitalizmu, čineći izlišnim za feudalno vrijeme neizbježnu direktnu uporabu sile. ${ }^{16} \mathrm{U}$ najtješnjoj vezi s takvim karakterom robe je i nepromjenjivost postojećeg koju je Adorno, eksplicirajući baš tu isprepletenost, isto tako nazvao fetišem jer u oba slučaja ono što je naš vlastiti proizvod, bio to produkt nekog određenog rada ili ukupnost našeg djelovanja, tretiramo kao živo i sa nezavisnom voljom kojoj se $\mathrm{k}$ tome još moramo i pokora-

13 T. W. Adorno (1979), Negativna dijalektika, 64.

14 K. Marx (1977), Temelji slobode, 7-9.

15 K. Marx (1974), Kapital. Kritika političke ekonomije (Prvi tom), 78.

16 Marx (1974), Kapital (pogl. Fetiški karakter robe i njegova tajna), 73-85. Za noviju raspravu o značaju koncepta fetiškog karaktera robe v. $M$. Heinrich (2012), 70-80. 
vati. Zato bismo mogli reći da je fetiški karakter robe u istom odnos spram fetiša nepromjenjivosti postojećeg kao što je pojedinačna roba spram načina proizvodnje koji je stvara.

Na Marxovo kontrastiranje osobne ovisnosti iz prijašnjih načina proizvodnje sa "ovisnošću o 'objektivnom poretku stvari' (o ekonomskim zakonima, tržištu, itd.)”, karakterističnim za kapitalizam, Marcuse će se nadovezati kako bi poentirao da usprkos historijskom nastajanju takvog kapitalističkog načina odnošenja sama "dominacija čovjeka nad čovjekom u društvenoj zbilji” predstavlja "povijesni kontinuum koji povezuje predtehnološki i tehnološki um”. Premda "društvo poduzima tehnološku transformaciju prirode" i time "mijenja bazu dominacije” (osobna se ovisnost postepeno nadomješta objektivnom), i što "sve efikasnije eksploatira prirodne i mentalne izvore i distribuira beneficije ove eksploatacije na sve široj osnovi” i dalje se zadržava hijerarhijska struktura. ${ }^{17}$

Tu dolazimo do problema, tj. do limita strategije koja se suprotstavlja fetišu nepromjenjivosti postojećeg tako što ukazuje na njegovu historijsku genezu. Naime, kada je u pitanju dominacija, ne možemo se uhvatiti za vrijeme kada je nije bilo nego možemo samo pratiti različite promjene u odnosima dominacije i kao mentalnu vježbu izabrati pod kojim odnosom dominacije bismo se najradije našli. Većina bi se danas, suočena s takvim izborom, odlučila za kapitalizam, ${ }^{18}$ no svrha naglašavanja povijesnog kontinuuma dominacije u kritičkoj teoriji dijametralno je suprotna apologiji kasnog kapitalizma kao optimalnog i humanijeg od svih vidova dominacije. To naglašavanje, nikako kao prilog tezi da su društveni odnosi dominacije neizbježni dio ljudske prirode, zapravo služi kao koncentrirani napad na i dalje prisutne razine brutalnosti koje su zapravo potpuno nepotrebne ako znamo razinu tehnološke razvijenosti našeg doba. "U početku, materijalna proizvodnja je bila toliko nerazvijena da je to davalo osnova za priču kako nema dovoljno za sve" ali "objektivne pretpostavke toga su se promijenile." ${ }^{19} \mathrm{~S}$ obzirom na neposrednu mogućnost obilja, princip

17 Marcuse (1968), 144.

18 Treba naglasiti da prve generacije radnika koji su doživjeli osvit kapitalizma sasvim sigurno ne bi izabrali taj način proizvodnje naspram onih prijašnjih o čemu snažno svjedoči posljednji dio prvog toma Kapitala (Takozvana prvobitna akumulacija), 630-685.

19 T. W. Adorno (2009), Minima moralia: Refleksije iz oštećenog života, $\$ 60$ (prijevod adaptiran). 
njenog neumitnog ograničavanja samo na izrazito malu skupinu ljudi, kako je već funkcionirao kroz prošlost, mora djelovati suvišno, ne samo u očima društvenih nekonformista već i ograničenih buržuja. Ali razina racionalnosti u upravljanja društvom značajno i kobno je manja od racionalnosti prisutne $u$ proizvođenju robe..$^{20}$ Svjestan toga, Adorno će 1964. u televizijskom intervjuu sa Blochom naglasiti da premda smo neke od utopijskih ciljeva već ostvarili poput "televizije" ili "kretanja većom brzinom od zvuka", ti ostvareni ciljevi izgubili su svoju utopijsku dimenziju. ${ }^{21}$ Ne zato što sâmo ozbiljenje utopijskog cilja razbija iluzije da se u njemu zaista krije utopija, nego zato što su realizirani utopijski ciljevi s kojima se kao čovječanstvo možemo pohvaliti mahom samo sredstava. Koliko god da su moćna, ipak su samo oruđa, dok je način njihove uporabe ono što zapravo određuje njihov utopijski karakter. Za Adorna, "što god da utopija jest, što god možemo zamisliti kao utopiju, ona je zapravo uvijek transformacija totaliteta” i, tako mišljena, utopija odgovara smislu našeg slogana. Upravo što se tiče realnog traženja nemogućeg, zanimljivo je Adornovo viđenje: "Da su ljudi prisegli na ovaj svijet onakav kakav jest i da imaju blokiranu svijest vis-a-vis mogućnosti, sve to ima vrlo duboki uzrok koji

20 Usp. T. W. Adorno (1991), The Culture Industry. Selected Essays on Mass Culture: "Through [an] adjustment to the technical forces of production, an adjustment which the system imposes upon them in the name of progress, men become objects that can be manipulated without further objection and thus fall far behind the potential which lies in the technical forces of production. But since as subjects men themselves still represent the ultimate limit of reification, mass culture must try and take hold of them again and again: the bad infinity involved in this hopeless effort of repetition is the only trace of hope that this repetition might be in vain, that men cannot wholly be grasped after all" (93). Iako se velikom i značajnom temom za Adornovu misao, masovnom odnosno popularnom kulturom, nećemo posvetiti u ovom radu, upućujem za daljnju raspravu na V. Biti (1987) i S. Buck-Morris (1977), 188-19o (v. također ovdje bilj. 75).

21 E. Bloch (1988), The Utopian Function of Art and Literature: selected essays, 1. U kontekstu ovog rada vrijedi izdvojiti da je Bloch bio mnogo entuzijastičniji oko '68. od Adorna i drugih pripadnika Frankfurtske škole te im je zamjerao defetizam, a Adornov nihilizam držao za utjelovljenje očaja i primjer loše negativnosti. Adorno je pak bio pod velikim utjecajem Blochova Duha Utopije, ali je iz tog djela prihvatio samo njegov kritički i revolucionarni impuls, ne i ideju religijske zajednice, obrušivši se na Blocha da je totalizirao i instrumentalizirao utopijsko. Usp. I. Boldyrev (2014), 167-177. 
je po mom mišljenju izuzetno povezan upravo sa blizinom utopije."22 Materijalna bliskost utopije ogleda se u činjenici da bi za njenu realizaciji dostajala tehnologija iz postojećeg načina proizvodnje, no spomenuti objektivni poredak stvari u podlozi kapitalističke proizvodnje trebao bi se potpuno promijeniti da bismo te proizvode mogli koristiti na utopijski način. ${ }^{23}$ "Ono čime negativna dijalektika prožima svoje skrućene predmete jest njihova mogućnost koju im je njihova zbilja oduzela, no ipak se u svakom od njih nazire". ${ }^{24}$ Dodajmo tome da je "utopija svijest mogućnosti” te da je upravo:

Moguće, a nikada neposredno zbiljsko, ono što zatvara put utopiji; usred postojećeg pojavljuje se stoga kao apstraktno. Neizbrisiva boja dolazi iz nebitkujućega. Mišljenje [...] koje, bez obzira koliko negativno dopire do nebitkujućeg, služi tome. Tek bi krajnja udaljenost bila blizina; filozofija je prizma koja lovi njezine boje. ${ }^{25}$

Ne trebamo biti zapljusnuti sjajem neizbrisive boje iz "nebitkujućeg" da bismo uvidjeli da je Adorno na svoj način ispisao naš slogan i prije '68., i to formuliravši ga također, naizgled paradoksalno, a u stvari kao što i priliči predmetu mišljenja, dijalektički kada je napisao da bi "tek krajnja udaljenost bila blizina”. Time nas upućuje da imamo s jedne strane objektivnu blizinu utopije, a s druge njenu potpunu udaljenost iz vizure subjekata koji su izgubili mogućnost konceptualizacije drukčijeg uređenja. Mogućnost je ta koja nas priječi i zato je moramo imati u negiranom obliku. Ono blisko u raširenom mišljenju predstavljaju primjerice figure domovine i sigurnosti za koje se "ljudi plaše da će gubeći njih izgubiti sve, jer ne znaju ni za kakvu drugu sreću, pa ni

22 Bloch (1988), 4.

23 Vraćajući se na kritiku fetišizma robe i nepromjenjivosti postojećeg Adorno neumorno podsjeća: "The society that impenetrably confronts people is nonetheless these very people", v. T. W. Adorno (1998), Critical models: Interventions and catchwords, 291. Odgovornost leži na subjektima: "The neon signs which hang over our cities and outshine the natural light of the night with their own are comets presaging the natural disaster of society, its frozen death. Yet they do not come from the sky. They are controlled from earth. It depends upon human beings themselves whether they will extinguish these lights and awake from a nightmare which only threatens to become actual as long as men believe in it." Usp. T. W. Adorno (1991), 96.

24 Adorno (1979), 64.

25 Adorno (1979), 67. 
sreću u mislima, već samo za perenirajuću neslobodu”. ${ }^{26}$ Samo s krajnjom udaljenosti u mišljenju od onog što se smatra bliskim, poželjnim i sigurnim mogli bismo doći u blizinu utopije.

Zato, čak i kad slogan shvaćamo kao ozbiljan imperativ, ne smijemo odustati od spajanja realnosti i nemogućnosti jer to dovodi do kratkog spoja zdravorazumskog načina mišljenja čiji nas rezultirajući strujni udar ne ostavlja u mraku sveopćeg relativizma i iracionalizma, nego naprotiv, omogućava da kroz drugu prizmu i u novom svjetlu sagledamo situaciju u kojoj se nalazimo. No, kako bi potkrijepili tvrdnju o neidentitetu dijalektike, iracionalizma i relativizma, moramo se još jasnije razračunati sa konzekvencijama negativnosti i proturječnosti kao nužnih za utopijsko mišljenje.

S kojim pravom se misao uopće može usuditi da proturječi zbilji? Naime, negiranje stvarnosti kakva jest ne krasi samo dijalektičku misao nego i mišljenje poslovičnih luđaka i sanjara iz starih epistemoloških trauma. Prateći ono što smo do sada izložili, mogli bismo reći da usporedba ne stoji jer nije u pitanju negiranje stvarnosti naprosto, nego je riječ o protivljenju ogrezlosti postojećeg u navodnoj nepromjenjivosti. No, ako bi se usporedba s ludilom mogla s tim argumentom donekle neutralizirati, ona sa sanjarstvom teško da bi. Kako možemo pokazati da je mogućnost koju naziremo u skrućenim predmetima stvar jave? Ekspliciranjem temeljnih vrijednosti Adornove i Marcuseove misli dobit ćemo odgovor na ovaj kompleks pitanja koja zapravo ocrtavaju problem povijesne objektivnosti, dobro poznat Frankfurtskoj školi. S njim se već na fundamentalnoj razini mora razračunati svaka kritička teorija društva ${ }^{27} i$ to mora učiniti na polju svojih "dvaju uporišta" u kojima analiza socio-ekonomskog stanja nužno "implicira vrijednosne sudove". Kako ih iskazuje Marcuse, ta neminova uporišta, tj. ti neizbježni sudovi, glase:

1. Sud da je ljudski život vrijedan življenja ili, preciznije, da može i treba biti učinjen vrijednim življenja. Ovaj sud je u osnovi svih intelektualnih napora; on je a priori teorije društva i iz njegova neprihvaćanja slijedi (što je sasvim logično) neprihvaćanje same teorije.

2. Sud da u danom društvu postoje određene mogućnosti za poboljšanje ljudskog života i određeni putevi i sredstva za realiziranje tih

26 Adorno, isto, 49.

27 Kritičko je ovdje mišljeno u širem smislu, kao teorije koje pored proučavanja žele i mijenjati društvo, a ne u užem koje označava samo Frankfurtsku školu. Usp. J. Bohman (2005). 
mogućnosti. Kritička teorije mora demonstrirati objektivnu vrijednost tih sudova, a demonstracija se mora odvijati na empirijskim osnovama. $^{28}$

Prvi sud zapravo je uvjet mogućnosti ne samo progresivnog mišljenja, nego mišljenja uopće; drugi je zapravo zahtjev koji je kritička teorija sama sebi postavila, naime da se na empirijskoj osnovi pokaže objektivna mogućnost njenih ciljeva. $S$ tim unutarnjim zahtjevom dijalektika kritičke teorije efektivno se razlučila od bilo kakvih zabluda i pukih sanja. Rečeni vrijednosni sudovi zapravo pokazuju dva aspekta dijalektičke misli o čijem međuodnosu ovisi njena istinitost.

\section{Dva aspekta dijalektičke istine}

Prvom vrijednosnom sudu kritičke teorije - koji izražava ono što ćemo nazvati afektivni a priori - prethode vrijednosti s kojim se prema Marcuseu desilo da je filozofija bila rođena, a to su sudovi da slobodu od mukotrpnog rada valja preferirati pred mukotrpnim radom, a inteligentan život pred glupim. ${ }^{29}$ Polazeći od tih uporišta, filozofija se susretala sa zbiljom koja je antagonistična spram takvih vrijednosti, svijetu u kojem promišljeni, reflektirani život nije jedini vrijedan življenja nego je pored fizičkih muka dodatna, mentalna klopka. No, filozofija se nije dala pokolebati zbog neumoljive zbilje, pa je kao reakciju udvojila stvarnost na nebitak - pojavu, neistinitu i neslobodu koja se nadaje kao realnost - i na bitak — pravu, istinitu i slobodnu stvarnost u kojoj se njena načela poštuju. Istina je zato vrijednost jer je bitak bolji od nebitka koji nije naprosto ništa, nego je prijetnja bitku, mogućnost njegovog uništenja.

Borba za istinu je borba protiv uništenja za spasenje bitka. Utoliko što borba za istinu "spašava" realnost od destrukcije, istina obvezuje i angažira ljudsku egzistenciju. Ona je bitno ljudski projekt. ${ }^{30}$

Nadovezujući se na poznatu i naprijed citiranu Adornovu misao, možemo reći da filozofija od svojih početaka djeluje kao prizma koja hvata neizbrisivu boju boljeg i smislenijeg života, no filozofija je samu sebe ponizila, postajući utješna afirmacija, ${ }^{31}$ onda kad je izvor

28 Marcuse (1968), 11.

29 Marcuse, isto, 126.

30 Marcuse, isto, 124.

31 Na to da se filozofija "mora čuvati htijenja da bude utješljiva” upozorio je Hegel u predgovoru Fenomenologiji duha (1987), 8. 
te boje pripisala realnom bitku, a ne onom još nebitkujućem koje će tek praktička djelatnost moći ostvariti. ${ }^{32}$ Varala je i sebe i druge "skrivajući da bez obzira kako pokreće svoje predmete u njima samima, tim predmetima mora i izvanjski nešto ulijevati”, jer "ono što čeka u samim objektima progovara tek intervencijom”, angažiranjem i mobiliziranjem snage koje su izvanjske domeni mišljenju. Naime filozofija kao bitno ljudski projekt "smjera na svoj vlastiti kraj" upravo "svojim vlastitim ozbiljenjem" ${ }^{33}$ Od samog početka ona zapravo nije bila vjerna toj svojoj najdubljoj unutarnjoj potrebi, pa se ogradila od aktivne borbe za istinu, i ograničila svoje temeljne vrijednosti na usku grupu ljudi koja je uistinu i bila slobodna od mukotrpnog rada. Time je bila u opreci spram univerzalne naravi istine, ali je udvajanjem stvarnosti apstrahirala od vlastitog povijesnog realiteta i izdigla istinu iznad nje. No s vremenom, svaka rigorozna misao se počela udaljavati od vlastitih temelja, tako uzdignutih iznad stvarnosti, logika je postala indiferentna prema objektima misli s kojim barata, sadržaj je time bio neutraliziran, a princip identiteta razdvojen od principa kontradikcije, pa tako ovo zadnje nije više moglo biti išta doli neispravno mišljenje.

Mišljenje je očišćeno od 'negativnog', koje se uvelike naziralo na počecima logičke i filozofske misli - [a] eleminiranjem [tog] iskustva, iz cjelokupne misli, koja treba da bude objektivna, egzaktna i znanstvena eliminiran je konceptualan napor da se održi napetost između 'jest' i 'treba da' i da se postojeće obrati u ime svoje

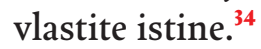

Želja da samo posjedovanje znanja promijeni čovjeka, da utječe, ne po svojim efektima na zbilju kao kada su u pitanju značajne tehnološke inovacije koje nepovratno mijenjaju život, nego da već samo znanje, jednom kad ga prenesemo, mijenja drugog, jer kada čovjek nauči "da vidi i zna što realno jest, on će djelovati u saglasnosti s istinom”, ostalo je samo to, puka želja. Ona se morala napustiti, jedinstvo vrijednosnih sudova i analize moralo se slomiti "jer je postajalo sve jasnije da

32 Usp. T. W. Adorno (1979), Negativna dijalektika, 67. Druga formulaciju iste misli iz Tri studije o Hegelu (1972), 79, još je izravnija: "Zraka koja u svim svojim momentima objelodanjuje cjelinu kao neistinu, nije drugo do utopija, utopija cjelokupne istine, koju još tek treba ozbiljiti”.

33 Adorno (1979), 45.

34 Marcuse (1968), 137. 
filozofske vrijednosti nisu rukovodile organizaciju društva niti transformaciju prirode. One su bile neefikasne, nerealne." ${ }^{5}$

Za Adorna i Marcusea nije problem što se znanstvena misao prestala voditi neefikasnim vrijednostima, nego to što osnova tih vrijednosti nije dijalektički prevladana u njoj tako da afektivni a priori ${ }^{36} \mathrm{sa}$ svojim nagonima i žudnjama ostane prisutan na stanovit način, a ne da bude jednoznačno uništen jer "čak i najudaljenije objektivizacije misli hrane se nagonima, tako da njihovo uništavanje znači uništavanje sâmih preduslova misli."

Točno je da se objektivno značenje spoznaje, sa objektivizacijom svijeta, sve više udaljava od nagonske osnove; točno je i da spoznaja ne uspijeva kada njen pokušaj objektivizacije ostaje pod stegom žudnje. Ali, ako nagoni, u misli koja više ne podleže njihovim činima, nisu u njoj u isti mah prisutni i prevladani, onda više ne može biti nikakve spoznaje, a misao koja je ubila želju, svog oca, podleći će osveti gluposti. ${ }^{37}$

U međuvremenu je znanost toliko napredovala da se čak i iz vizure objektiviranog svijeta koju nam pruža može dokazati istinitost Adornovog mišljenja. Rezoniranje se više ne stavlja u dihotomiju sa afektima, nego se promatraju kao dio kontinuuma. ${ }^{38}$ Dapače, prijašnji ideal racionalnog promišljanja, oslobođenog od svih afekata, prokazan je kao iracionalan. ${ }^{39}$

35 Marcuse, isto, 126.

36 Naglašavanje afektivnog a prioria nije specificum Frankfurtske škole, v. A. Honneth (2008).

37 Adorno (2009), $\$ 79$ (prijevod adaptiran).

38 Usp. Y. J. John et al. (2013), Anatomy and computational modeling of networks underlying cognitive-emotional interaction, 20: "We have argued that rather than being opposing forces, cognition and emotion can be seen as points on a continuum or gradient of flexible processes required for adaptive categorization of, and response to, changes in the external and internal environment of an organism. [...] The functional continuum is based on the robust connections between areas associated with cognition and those associated with emotion."

39 Usp. C. Malabou (2016), 43-44: "Nije moguće postojati a da se ne bude aficiran. Taj temeljni uvid otvara neurobiologiji nov put, jer ona sada uzima u obzir ključnu ulogu emocija u životu mozga, odnosno u jedinstvu organizma, kompleksa sačinjenog od duha i tijela. Um i kognicija ne mogu se razviti ni normalno vršiti svoje funkcije ako ih 
Usprkos tim spoznajama, osveta gluposti je došla. Imali li jasnijeg i značajnijeg primjera za to od katastrofalne situacije sa globalnim zatopljenjem. Marcuse, iako svjestan da je znanstveno mišljenje često u sukobu sa dojmovima neposrednog iskustva, svejedno je smatrao da ono "ne razvija pojmove koji u sebi nose protest i odbijanje" jer "nova znanstvena istina kojom znanstveni pojmovi oponiraju prihvaćenoj istini ne sadrži osudu postojeće stvarnosti” nego samo osudu dotadašnjih teorijskih shvaćanja. ${ }^{40} \mathrm{U}$ međuvremenu se i to promijenilo jer neosporno je da znanstveno mišljenje u vezi globalnog zatopljenja sadrži takav snažni protest protiv postojećeg stanja stvari. ${ }^{41}$ Ali takva osuda ne može biti dovoljna ako u sebi ne sadrži i imperativ čija se istinost može dokazati samo preko dijalektičkog promatranja odnosa, s jedne strane granica mogućnosti onog realno izvedivog, promatranih iz perspektive sadašnjeg i u povijesti prisutnog, a s druge strane potreba, žudnji i nadanja, koje se iz perspektive onog prvog ne mogu realizirati, ali su nužni i neophodni da bi se spriječila klimatska katastrofa. Bez imperativnosti dijalektičkih istina kapitulirat ćemo pred nemogućnostima, umjesto da ih svim silama tražimo, jer su nam, u ovom primjeru sasvim doslovno, jedini način da se spasimo od opasnog degradiranje kvalitete života u sasvim bliskoj budućnosti. ${ }^{42}$

Dijalektička istina ima, kako smo rekli, svoja dva aspekta. Prvi je njen afektivni apriori koji nalaže da je racionalan "onaj mod mišljenja i djelovanja koji pokreće reduciranje ignorancije, destrukcije, brutalnosti i ugnjetavanja. ${ }^{43}$ Drugi aspekt, kojem se sada okrećemo, povijesni je karakter dijalektičke istine koji nalaže da se zahtjevi afektivnog a prioria trebaju povijesnom praksom prevesti u realitet kako bi se pokazala njihova objektivna valjanost: vrednote vezane za društvene alternative tek tada postaju činjenice.

Dijalektika polazi od apstrahiranja koje ne prihvaća dani univerzum

ne podupiru afekti. Umovanje bez žudnje nije umovanje (...) Selektivna redukcija emocija remeti racionalnost barem u onoj mjeri u kojoj to čine i pretjerane emocije."

40 Marcuse (1968), 137.

41 Za jedan od recentnijih primjera v. Järvensivu et al. (2019).

42 Usp. R. Levitas, (2008), 90: "Environmental crisis provides the opportunity, as well as the necessity for this. It marks the shift from 'there is no alternative' to 'there is an alternative to an alternative' - a recasting, perhaps, of 'be realistic, demand the impossible."

43 Marcuse (1968), 139. 
činjenica kao konačan kontekst valjanosti [te njena] analiza transcendira činjenice na osnovu njihovih pripitomljenih i negiranih mogućnosti [a to čini] na temelju rigorozno povijesnog karaktera trascendencije. "Mogućnosti" moraju biti unutar dohvata analiziranog društva; one moraju biti odredljivi ciljevi prakse. ${ }^{44}$

Osim objektivnih mogućnosti za drukčiji socio-ekonomski ustroj, u danom društvu već moraju i obitavati subverzivne tendencije i snage koje zahtijevaju takvu alternativu te prizivaju transcediranje postojećeg, i to preko jasno odredljivih ciljeva prakse. Takav povijesni karakter dijalektičkih istina njihova je brana od proizvoljnosti, neodređenosti, a samim time i beznačajnosti. Logika tih istina suprotstavljena je kako metafizičkoj i formalnoj logici, tako i konkretnosti neposrednog iskustva ako je ono "suženo na stvari kako se pojavljuju i kako slučajno jesu" jer je pojavnost te vrste uhvaćena u dobro nam znane fetišizme. Iskustvo dobiva svoju istinitost tek kada iskustvujući subjekt razumije svoj svijet kao "povijesni univerzum u kojem su postojeći fakti djelo čovjekove povijesne prakse”, i zato promjenjivi ljudskom praksom. Kada tako pojmljena povijesnost uđe u dijalektičko mišljenje, struktura misli se konkretno povezuje sa strukturom stvarnosti. "Logička istina postaje povijesna istina". ${ }^{45}$ Dolazi se do odredljivih ciljeva, ispituje se njihova mogućnost ozbiljenja i reflektira se o svačijem položaju u reprodukciji postojećeg.

Na prvi pogled, ovako postavljena situacija navodi nas na to da promatramo povijest kao sferu koja daje istinosnu vrijednost našoj dijalektici. Povijest određuje hoće li se dijalektička misao realizirati, postati činjenica, ka čemu ona svojom povijesno-praktičkom dimenzijom nužno tendira, ali povijest, iako pritom konkretizira misao i spaja je sa stvarnošću, ipak nije zalog njene istinosne vrijednosti, to je njen prvi aspekt, afektivni a priori.

Nadalje, pristajanjem na povijest kao sferu koja pokazuje istinosni sadržaj misli, neminovno dolazimo do revaloriziranja u ne više kritičko, nego apologetsko shvaćanje postojećeg stanja društva naspram povijesnog kontinuuma odnosa dominacije. ${ }^{46} \mathrm{Uz}$ to moramo zami-

44 Marcuse, isto, 11-12.

45 Marcuse, isto, 138.

46 T. W Adorno (1979), 129-130: “To što je prošlost prešla preko nekih pozicija poštuju kao sud o istinitosti tih pozicija samo oni koji smatraju povijest sudnjim danom. Vrlo često ono što je odbačeno a teorijski nije apsorbirano tek kasnije pokazuje svoj istiniti sadržaj. To je čir u 
jetiti, kada bismo bespogovorno pratili ritam povijest u pogledu teorije, nesumnjivo bi većinu, ako ne i sve mislioce iz ovog rada, morali ostaviti u ropotarnici. Što se moglo smatrati u većoj mjeri nepovratno pregaženim poviješću nego marksizam u devedesetima, onako zasut razvalinama jednog zida?

Kao argument protiv takve apologetske nastrojenosti spram povijesti poslužit će nam Žižekova kritika Spinoze. Ne bi bilo teško pokazati da je Spinoza jedan od najprogresivnijih mislilaca u povijesti filozofije, ${ }^{47}$ što nas priječi da kritiku njegove krucijalne ograničenosti, a to je negativni stav o uključivanju žena u politički život, otpišemo kao anakronu. Spinoza se otvoreno pita, jesu li žene pod vlašću muškaraca po naravi ili zato što je to tako društveno određeno, te sam kaže da ako je to određeno, onda ni jedan validni razlog ne priječi da žene uistinu budu uključene u političku vlast. No, onda se poziva upravo na iskustvo, i dalje, na povijest, kako bi konstatirao da potčinjeni položaj žena proizlazi iz njihove slabosti.

Kad bi žene po naravi bile jednake muškarcima, i kad bi po duševnoj snazi i duhu, a u tome i jest najveća ljudska moć, a slijedom toga i pravo, bile jednako snažne, onda bi se zasigurno među tolikim i tako različitim narodima morali naći neki u kojima oba spola ravnopravno vladaju kao i drugi u kojima žene vladaju muškarcima i tako ih odgajaju da budu slabijeg duha; kako se to nigdje nije dogodilo, onda bez ikakve ograde može ustvrditi da žene po naravi nemaju jednako pravo kao i muškarci nego ga moraju ustupiti $[. ..] .^{48}$

Fascinantno u ovom odlomku jest to što se pojavljuje mogućnost da se određeni spol može sistematski odgajati tako da bude slabijeg duha. Spinoza ne nalazi primjer za to, jer bi mu za to poslužio samo neki u kojem bi žene bile na poziciji moći i isključivale muškarce iz političkog života, stoga pristaje na naravnost nejednakosti između spolova. To što inzistira na onom postojećem i onome što je to postojeće prethodilo kao jedinom horizontu mogućnosti, zbog čega je prisiljen odbaciti otvorenu mogućnost da uzrok političke neravnopravnosti između spolova nije naravni, već društveno određeni i zato promjenjivi, neizbježno proizlazi iz pristajanja na povijest kao sferu u kojoj

vladajućem zdravlju; u promijenjenim situacijama upozorava na sebe.”

47 Vidi primjerice E. Balibar (1994), Masses, classes, ideas: studies on politics before and after Marx, 3-39.

48 B. Spinoza (2006), Politička rasprava, 147. 
se dokazuje istinitost stavova o društvu i ljudima. Zbog toga ga Žižek i kritizira retorički se pitajući

(...) zar nije Spinoza sušta suprotnost židovskoj-Levinasovsko-Derridaovsko-Adornovskoj nadi u konačno Spasenje, suprotan ideji da ovaj naš svijet ne može biti "sve što jest" —zadnja i ultimativna Istina, i da bi se trebali držati obećanja neke Mesijanske Drugosti? ${ }^{49}$

Žižek prepoznaje Nietzscheov amor fati kao homolognu poziciju Spinozinom prihvaćanju stvarnosti, a Adorno, kao jedan od spomenutih u židovskoj trijadi nade, pruža izuzetnu kritiku tog koncepta. Prvo hvali Nietzschea da je pružio najjači argument protiv teologije, kao i metafizike općenito, a to je da "brkaju nadu sa istinom jer to što je nemoguće živjeti sretno ili čak bilo kako, bez ideje o nečemu apsolutnom, ne dokazuje legitimnost takve misli." ${ }^{50}$ Ali s druge strane, ono što Nietzsche uči i smatra svojom najdubljom prirodom jest ljubav prema sudbini, što je nagnalo Adorna da se zapita:

(...) je li zaista ispravnije voljeti ono što nam se dešava, afirmirati nešto zato što je to što jeste, nego da za istinu uzimamo ono čemu se nadamo. Nije li to isti onaj pogrešan zaključak koji vodi od postojanja 'stubborn facts' do njihovog uzdizanja u najvišu vrijednost, koje je kritizirao u prelazu od nade ka istini? [...] U oba slučaja, riječ je o bijedi prilagođavanja, koja, da bi se nekako podneo užas svijeta, pripisuje realnost željama i smisao besmislenoj prisili. (isto)

Adorno brani teologiju i metafiziku od Nietzscheove optužbe tako što ih sve zajedno optužuje kao neznane sudionike $u$ istom zločinu, tj. kardinalnoj neistini predstavljanja istinitim postojanja koje smo prepoznali kao loše, samo zato što smo to prepoznali. Što će reći, samo zato što smo iznašli načine da se nosimo sa takvim lošim postojanjem, bilo tako što pripisujemo realnost teološkim i metafizičkim željama ili tako što ničeanski dajemo smisao besmislu: "Na kraju, nada, koja izmiče stvarnosti tako što je negira, jedini je oblik u kojem se ukazuje istina. Bez nade, ideja o istini bila bi jedva pojmljiva” (isto). Zločin te-

49 S. Žižek (2004), Organs without Bodies: Deleuze and consequences, 39.

Za kritiku Žižekovog shvaćanja Spinoze v. T. Stolze (2014). Premda Stolze ide u potankosti Žižekove recepcije Spinoze, ne osvrće se, tj. ne osporava Žižekovo podcrtavanja i objašnjavanje Spinozinog stava prema uključenju žena u politički život.

50 Adorno (2009), \$ 61 (prijevod adaptiran). 
ologije nije u tijesnoj vezi nade $\mathrm{i}$ istine, nego baš suprotno, $u$ njenom konformistički pasivizirajućem, a na koncu izdajničkom stopiranju dijalektičke kretnje svojstvene istini koja proizlazi iz afektivnog aprioria. Nada je forma istine, ali kada u njen sadržaj uđe povijesno i postojeće, a ona ne nastavi negirati takav sadržaj, ne nastavalja se upinjati da obrati i ukine ono što jest zbog onog što treba da bude, onda je došlo do pripisivanja realnosti željama. ${ }^{51}$ Kada u postojećem već vidimo ono što treba da bude, ali na takav način da je naše djelovanje ograničeno jer trebamo samo pratiti pravila i izvršavati rituale, koje je donio neki Mesija kako bi dospijeli do tog što treba da bude, i to najčešće u nekom zagrobnom životu, onda govorimo o izdaji unutarnjeg mehanizma istinâ afektivnog aprioria koje traže transcediranje postojećeg, ali ne priznaju neimanentno spasenje u nekoj transcedenciji. Istina, pored toga što se ukazuje u obličju nade, kao svoj uvjet ima potrebu da glas dade patnji te da se ona prepozna i odstrani. ${ }^{52}$

Tjelesni moment objavljuje spoznaji da patnje ne treba biti, da treba biti drukčije. Bol govori: neka mine. Zato ono specifično materijalističko konvergira sa kritičkim, sa praksom mijenjanja društva. ${ }^{53}$

To što se nekim patnjama, recimo patnjama žena isključenih iz političkog života, nikada do određenog trenutka u povijesti nije niti pridavala pozornost, a kamoli da je taj problem rješavan, ne znači da se te patnje nisu mogle odstraniti ranije ili da se nikad i ne bi mogle odstraniti. Taj primjer, kao jedan od ključnih historijskih iskustava za promišljanje emancipacije i poboljšanja ljudskog života, uči nas da dijalektičke istine ne ovise o sudu povijesti, no s druge strane, iste te istine moraju biti povijesno situirane, time konkretizirane i usmjerena na praksu. U logici stavova, tj. vrijednosti afektivnog aprioria, jest da se stavovi nikada ne mogu zadovoljiti samo sa statusom istine, nego uvijek žele postati realizirani fakti. One su u poziciji u kojoj se nalazimo kada primjerice imamo samo točan rezultat na ispitu iz matematike, a znamo da to nije dovoljno kako bi nam se priznalo rješavanje zadatka jer za to bi još trebali napisati izvod, odnosno pokazati postupak kojim smo došli do točnog rezultata. Istine afektivnog aprioria zato ne mogu

51 O značaju nade kod Adorna v. T. Jütten (2019) i J. Winters (2014); za širi problem krize nade iz vizure kritičke teorije v. A. van der Berg (1980) i S. Amsler (2009).

52 Usp. K. Schick (2009) za jedan primjer razrade te Adornove poznate misli.

53 Adorno (1979), 175. 
ostati u svojoj sferi i samozadovoljno uživati u svojoj točnosti jer je tada gube, nego moraju smjerati na praktičko postupanje i povijesno izvođenje ako žele zadržati svoj istinosni karakter.

No čak ako i prihvatimo tako pojmljenu istinu dijalektičke misli, to i dalje ne upućuje nužno da je njezin cilj, postajanje činjenicom, realno ostvariv. Teško je ne složiti se s tezom o postojanje tehnologije i resursa da se ispune određeni utopijski ciljevi, ipak je to onaj aspekt kritičke teorije za koji ne treba dijalektika i koji je besprijekoran u svojoj empirijskoj dokazivosti. ${ }^{54}$ No, prosta ispravnost te teze ne može otklonuti sumnju da postoje intrinzični razlozi zašto je ljudska vrsta tako spoznajno sposobna i tehnološki ostvarena, a istovremeno fatalno i nepremostivo nesposobna da tu istu sposobnost i naprednost upravi kako bi primjerice u potpunosti eliminirala glad u svijetu, taj realno ostvariv i minimalan, ali po svojoj naravi svejedno utopijski cilj.

Adorno će u pogledu utopijskih ciljeva i zahtjeva ustrajati na tome da će "nježno", što će reći nebarbarsko, "biti samo ono najgrublje" od ciljeva, primjerice "to što više nitko neće biti gladan". To govori s obzirom na standardne "utopijske slike nesputanog, energičnog, kreativnog ljudskog bića" jer takve koncepcije ostaju "zaražene fetišizmom robe" $\mathrm{i}$ idealom konstantnog rasta:

Ideja o nesputanom delovanju, o neprekidnom stvaranju, o jedroj nezasitosti, o slobodi kao intenzivnoj aktivnosti, hrani se buržoaskim shvatanjem prirode, koje je oduvek služilo tome da opravda društveno nasilje kao nešto neopozivo, kao sastavni deo zdrave večnosti. Upravo zato, a ne zbog neke navodne težnje ka uravnilovci, pozitivni nacrti socijalizma, koje je Marks odbijao, ostali su ukorjenjeni u barbarstvu. Ono od čega treba zazirati nije pad čovječanstva u dokono izobilje, već divljačko širenje nečega što pod maskom univerzalne prirode ostaje društveno - kolektiviteta opsjednutog slijepom, mahnitom aktivnošću. ${ }^{55}$

S obzirom na stanje planete, nježnije i mnogo više utopijski nas se doima ono što Adorno priželjkuje nego želja milijarderâ da lete svemirom:

Možda će istinskom društvu dosaditi razvoj; možda će, u svojoj slobodi, ono ostaviti mogućnosti neiskorištenim, umjesto da pod sumanutom prisilom juriša na udaljene zvijezde. Čovječanstvo

54 Usp. T. W. Adorno (1979), so.

55 Adorno (2009), $\$ 100$ (prijevod adaptiran). 
koje više neće znati za oskudicu, počet će sticati predstavu o varljivoj i jalovoj prirodi svih dotadašnjih aranžmana za izbjegavanje oskudice, koji su bogatstvo koristili samo zato da bi oskudicu reproducirali na još širem planu” (isto).

Neumoljivom nužnošću ipak se dolazi do pitanja, zašto bi nade i želje, pa makar bile i one koje dijeli čitavo čovječanstvo, upućivali na objektivnu valjanost i mogućnost postojanja onoga čemu se nadamo i što želimo? Adorno će na ovo odgovoriti naoko izenađujuće, iznoseći svoje mišljenje da kada ne bi bilo ni trunke istine u ontološkom dokazu boga, ne bi moglo biti ni utopije. ${ }^{56}$ Tako naime čita i Hegelovu ${ }^{57}$ obranu ontološkog dokaza od Kantove ${ }^{58}$ kritike, ne kao zamračenje uma koje si želi pripisati moći kojih nema, nego kao "utopijsku nadu da blok, 'granice mogućnosti spoznaje' nisu ono posljednje”, da bi se uspjeh mogao postići usprkos svim dokazima za suprotno, "da će duh u svim svojim slabostima, uslovnosti i negativnosti sličiti istini i stoga biti valjan za spoznaju istine”. Adorno smatra da se nekada s pravom isticala "drska odvažnost Hegelovog učenja o apsolutnom duhu", ali se s obzirom na naše trenutno intelektualno stanje "predstava o apsolutnosti duha pokazuje kao spasonosni korektiv" jer se njime ispravlja "osakaćena rezignacija današnje svijesti koja je uvijek spremna da zbog vlastite slabosti još jednom” podupre i pristane na "poniženje koje joj je pričinjeno od nadmoćnosti slijepog postojanja".

Uz ovakvo čitanje možemo dodati da za razliku od eklatantnog pripisivanja realnosti željama ontološkog dokaza o Bogu, ontološki dokaz o utopiji može se poslužiti materijalom sa ove strane iskustva te se tako konkretnije utemeljiti. Usprkos ovim ogradama, našem će suvremenom duhu svaka primjesa religijske svijesti i njenih argumenata, pogotovo tako notornih kao što je ontološki dokaz o Bogu, i to baš u ovako krucijalnom momentu dokazivanja realne mogućnosti utopije, činiti nedopustivim i duboko diskreditirajućim. No, takva reakcija, premda potpuno razumljiva s obzirom na povijesno nasljeđe religija, zapravo ide u korist društvene iracionalnosti u kojim su osnažen i relevantne iste te religije, te tako ide protiv onih umnih tedencija čiji su napori i izborili značajne, ali nažalost i dalje nedovoljno visoke

56 E. Bloch (1988), 16.

57 G. F. W. Hegel (1988), 181-189.

58 I. Kant (1998), 563-569.

59 Adorno (1972), 42. 
razine sekularnosti koje uživamo. Kritizirati Adorna zbog religijskih primjesa, išlo bi u korist klimi koja omogućava da religije ostanu nedopustivo bitni politički i društveni faktori. Logiku po kojoj se do toga dolazi objasnili su sami Adorno i Horkheimer:

Nipošto ne sumnjamo - a u tome jest naša petitio princpii- da se sloboda u društvu ne može odvojiti od prosvijećenog mišljenja. Ali, ujedno mislimo da smo podjednako razgovjetno spoznali kako je već u samom pojmu ovog mišljenja, a ne samo u konkretnim historijskim formama društvenim institucijama u koje je zapleteno, sadržana klica onog nazadovanja do kojeg danas svuda dolazi. Ukoliko prosvjetiteljstvo ne prihvati refleksiju o tim nazadnim momentima, zapečatit će vlastitu sudbinu. Time što promišljanje o destruktivnosti napretka ostaje prepušteno njegovim neprijateljima, slijepo pragmatizirano mišljenje gubi svoj dokidajući karakter, pa stoga i odnos spram istine. ${ }^{60}$

No, usprkos takvoj mogućnosti diferenciranja, kao i već spomenutoj decidiranoj imanentnosti dijalektičkih istina naspram onih teoloških, Adorno svejedno priznaje da je pitanje o eliminaciji smrti ključno i neizbježno za utopiju. ${ }^{61}$ To dovodi utopijsku misao do ozbiljnih problema čijem ćemo pokušaju rješavanja posvetiti kraj ovog rada.

No prije toga, vratimo se nakratko na problem neoperabilnog imperativa. Premda dijalektička logika objašnjava i opravdava smislenost našeg slogana upravo u njegovoj naizgled kontraproduktivnoj proturječnosti i negativnosti, taj početni problem, koji nas je i nagnao na ova promišljanja, nije tako nadiđen nego se ponovno pojavio u novom ruhu istinâ afektivnog aprioria koje žude za vlastitim ozbiljenjem. Ostaje to da bi kritična masa mogla odgovoriti na poziv iz slogana, prvo ga treba razumjeti, upravo u ovako kompleksnom dijalektičkom obliku i to zato što "cilj mora biti operativan u sredstvima kojima se zadobiva”. ${ }^{62}$ Primjerice, u vjerovatno svakom revolucionarnom scenariju gotovo je neminovno da bi se trebalo služiti nekim formama nasilja kako bi se postigle suštinske promjene. ${ }^{63}$ No, takvo korištenje nasilja

60 Usp. M. Horkheimer i T.W. Adorno (1989), Dijalektika prosvjetiteljstva: filozofijski fragmenti, 9.

61 E. Bloch (1988), 8.

62 Marcuse (1968), 54.

63 I dok "nasilje, manipulacija i lukave taktike ugrožavaju cilj kojem navodno služe i tako se svode na puka sredstva”, s druge strane 
moralo bi biti vrlo precizno, a oni koji bi to provodili, odnosno koristili kao sredstvo, morali bi biti do u tančine osviješteni u pogledu utopijskog cilja. Trenutno stanje dakako priječi da takva osviještenost bude moguća za više od nekolicine privilegiranih, koji u svom malom broju ostaju nepremostivo impotentni.

Oni koji razmišljaju u formi slobodnih, distanciranih, objektivnih procjena nisu u stanju uvažiti iskustvo nasilja, koje u stvarnosti poništava upravo takav oblik razmišljanja. Skoro nerješiv zadatak sastoji se u tome da ne dopustimo da nas zaglupe ni tuđa moć, niti vlastita bespomoćnost. ${ }^{64}$

Zahtjev da cilj bude prisutan u revolucionarnim sredstvima predstavlja skoro nerješiv zadatak. ${ }^{65}$ Međutim, ne možemo zbog pretjerane zahtjevnosti odustati od zadatka, a da time ne riskiramo teror i izdaju cilja koji su kao mračna i krvava sjenka pratili sve velike revolucije. Također, ne možemo prestati pokušavati, ni zbog unutarnje nužnosti samih dijalektičkih istina, riješiti taj skoro nerješivi zadatak kojeg one susreću u svom ozbiljenju.

Gledano iz kuta ovih promišljanja, otpor prema instrumentalizaciji, koju posjeduje imperativ iz našeg slogana, bio bi rezultat prisvajanja logike koja nalaže da cilj mora biti prisutan u sredstvima. Konkretnije, dijalektika nalaže "da sâmu antitezu između sredstava i ciljeva [...] treba kritizirati” jer je "i jedno i drugo u buržoaskoj misli postvareno, a ta okamenjena antiteza je dobra za svijet koji ju je proizveo, ali ne i za napor da se on promijeni." ${ }^{66}$

\section{Negativni teolog iz bjelokosne kule}

Jedno od takvih zaglupljivanja zbog vlastite bespomoćnosti detektirao je Adorno kod studentskih radikala koji su akcionistički zahtijevali revoluciju odmah i sada (riječ je o '68. i '69. godini u Njemačkoj).

"verovanje da bi slepu igru sredstava mogao da sumarno zameni suverenitet racionalnih ciljeva [...] je buržoaski utopizam.” Usp. T. W. Adorno (2009), dodatak X.

64 Adorno (2009), $\mathbb{3} 34$.

65 Usp. H. Marcuse (1970), Five lectures - Psychoanalysis, Politics and Utopia, 80: "In order for the mechanisms to be abolished, there must first be a need to abolish them. That is the circle in which we are placed, and I do not know how to get out of it."

66 Adorno (2009), dodatak X (prijevod adaptiran). 
Iako je imao razumijevanja za njihov ideal neposrednog djelovanja vidjevši ga kao reakciju na integriranje nekada progresivnih organizacija u status quo kojem su donedavno žestoko oponirale, Adorno ne pristaje na nestrpljivost sa teorijom koju takvi ideali nose, kao ni na željenu fuziju teorije i prakse. Ta nestrpljivost ne vodi subverzivnu misao dalje od nje same do željenog ozbiljenja promišljenih i potrebnih promjena, nego dovodi do akcija koje su ispod razine smislenosti, do pseudo-aktivnosti koje su samoj sebi svrha, a tako se strastveno rade jer njihove aktere pošteđuje shvaćanja vlastite bespomoćnosti. ${ }^{67}$

Ti akteri u ioniziranoj atmosferi nakon '68. počeli su glasno optuživati Frankfurtsku školu da je kritična u teoriji, a konformistička u praksi, te da su njeni članovi, rezignirani u svojim sinekurama, modeli teoretičara iz bjelokosne kule. No, za Adorna se teško moglo reći da nije bio angažirani intelektualac. Naprotiv, jedno od njegovih zadnjih značajnih zalaganja oko konkretnih problema u javnoj sferi bilo je protestiranje protiv donošenja zakona o izvanrednom stanju u Zapadnoj Njemačkoj koji je htio značajno smanjiti određena građanska prava u slučaju da prosvjedi i nemiri prijete destabilizaciji države. Zakon je ipak izglasan, i to vrlo značajnog datuma, 30. maja 1968. No, studentski radikali i izvanparlamentarna opozicija zamjerali su mu što ih nije više i jasnije podržao. ${ }^{68}$

Njihovo nezadovoljstvo se potom počelo snažno manifestirati. Adorno je za njih uskoro bio mrtav kao institucija pa su mu onemogućavali da održi nastavu bukom zbog čega je morao otkazati svoj seminar sasvim prigodnog sadržaja - Uvod u dijalektičko mišljenje. Nadalje lijepili su plakate i bacali letke koji su ga prokazivali kao izdajicu, a na ploči su mu jednom napisali: "Tko god dragom Adornu dade kontrolu, do kraja svog života će sačuvati kapitalizam." ${ }^{69} \mathrm{U}$ jednom od znamenitih incidenata iz tog razdoblja, tri studentice su mu u predavaonici pokazale gole grudi uz sugestivnu pantomimu da bi se vidjelo kako će mislilac, koji je u teoriji tako snažno kritizirao seksualnu represiju i branio tjelesnost od klasičnih filozofskih napada, reagirati kada bude suočen sa neočekivano obnaženim tijelima u praksi. ${ }^{70} \mathrm{U}$ tom specifičnom slučaju, Ador-

67 T.W. Adorno (1998), 290-292). Za pseudoaktivnost v. također T. W.

Adorno (1991), 194 i T. W. Adorno (2002), 17.

68 Vidi uvod G. Richtera u T. W. Adorno (2002), 12-14.

69 Vidi uvod E. Leslie u T.W. Adorno i H. Marcuse (1999).

70 T. W. Adorno (2002), Who's afraid of the ivory tower? A conversation with 
no je posramljen izašao iz predavaonice, ali se nastavio zalagati za ono što je vidio kao progresivno razdvajanje teorije i prakse, što je pripisivao i zrelom Marxu. Kada su ljudi zatvoreni i očajnički žele pobjeći van, teško da se može precizno razmišljati o situaciji. Ali baš zato što je mišljenje otežano objektivnim uvjetima - tako bi se mogao sažeti Adornov stav - ne bismo trebali našem razumljivo paničnom djelovanju dati primat. ${ }^{71}$

Kad je u pitanju djelovanje radikalnih studentskih pokreta, Marcuse ih nije smatrao tako paničnim i nepromišljenim. Naprotiv, mislio je da bi mogli izvršiti potrebnu socijalnu intervenciju, doduše ne kao revolucionarna snaga po sebi (takav stav je odbacio kao besmislicu), već kao možda i najjači katalizator za veće promjene, kakav su tih godina iskristalizirali u SAD-u. Iako je Marcuse također bio protivnik neposrednog prijenosa teorije u praksu, svejedno je smatrao da u nekim historijskim momentima teorija mora postati jedno s praksom, ako ne želi iznevjeriti vlastitu istinu. Bio je ponosan na utjecaj kako svoje tako i Adornove teorije na studente, te, iako je priznavao da su racionalni elementi duboko isprepleteni sa iracionalnim elementima u pokretu, bio je spreman podnijeti bol iracionalnih postupaka koje je nazivao patricidom gdje mladi aktivistički naraštaj nema želju za obuzdavanjem psihološkog mehanizma što ih više motivira nego razmirice u mišljenju da idu dodatnim i često nepotrebno nasilnim žarom protiv vlastitih teorijskih očeva. Adorno se složio da praksa nekada gura teoriju dalje, ali je ipak smatrao da s obzirom na objektivnu situaciju to nikako nije slučaj, da je u pitanju ogoljeni i brutalni prakticizam koji uopće nema veze s teorijom, pa konzekventno, ni s promišljenim i potrebnim djelovanjem. Posebice je zamjerao radikalnim studentima neodgovorno pozivanje na nasilje s obzirom na moguću kontrareakciju regresivnih snaga. ${ }^{72} \mathrm{U}$ osudi nasilja Adorno

Theodor W. Adorno, 18: "To think that they did this to me, of all people, someone who has always opposed any kind of erotic repression and sexual taboo! To mock me and to loose three girls dressed up as hippies on me! I found that repulsive. The comic effect achieved by this was nothing more than the reaction of a philistine who giggles 'he-he!' at the sight of a girl with naked breasts. This nonsense was naturally planned in advance."

71 Usp. Marginalia on Theory and Praxis, T. W. Adorno (1998), 259-279. Za refleksiju i kontekstualizaciju tog rada v. F. Freyenhagen (2014).

72 T. W. Adorno i H. Marcuse (1999). 
nije bio rigidan kategorični pacifist ${ }^{73}$ svjestan toga da je inače potpuno legitimna averzija prema svakom vidu nasilja neminovno distorzirana privilegijom onih koji nisu primorani na takvo djelovanje. ${ }^{74}$ Nažalost česta je politička situacija da subverzivne snage nemaju taj luksuz, no to čini posezanje nekih radikala iz relativne udobnosti zapadnoeuropskih demokracije za nasiljem kao autolegitimacijom još manje prihvatljivim.

Iako su obojica bili uvučeni u patricidne inscenacije, iz prepiske koja sačinjava raspravu između Marcusea i Adorna vidljivo je, pored oštroumnosti obojice, da su te situacije puno teže padale Adornu te da se mnogo manje elegantno i staloženo znao u njima ponijeti. Adorno je doduše svoje slabosti otvoreno priznavao, znao je da su njegova izrazita osjetljivost kao i tankoćutnost omogućeni njegovom pozicijom u društvenoj podjeli rada, ali i deformirani s obzirom na ekonomski osnov na kojem se ta podjela dešava. "Filozofijskom iskustvu uopće ne bi pristajala elitarna umišljenost. Ono mora samo sebe razmotriti s obzirom na to u kojoj je mjeri, po svojim mogućnostima u postojećem, kontaminirano postojećim, a konačno klasnim odnosima".75 Upravo se na Adorna ustalilo gledati kao na tvrdokornog elitista i to zbog njegovih nazora o umjetnosti i posebice načina konceptualiziranja popularne, odnosno masovne kulture kao kulturne industrije. ${ }^{76}$ Ipak, od tako jednostrano negativne recepcije kulturne industrije kao nusproizvoda elitističkog refleksa odvraćaju nas brojna Adornova promišljanja protiv elitarnosti, kakva što smo vidjeli u tekstu kao i druga mjesta. ${ }^{77}$ Bjelokosna kula ima svoje uporište u kontaminiranom sistemu, ali ujedno i najbolja točka gledanja za smislene kritike takvog stanja stvari. Adorno je kao jednu od gorkih ironija doživljavao činjenicu da su samo oni koji su poput njega rođeni u dobrostojećim

73 T. W. Adorno (2002), 18-19.

74 T. W. Adorno (1998), 289-290.

75 Adorno (1979), 56.

76 Vidi istoimeno poglavlje iz Dijalektike Prosvjetiteljstva uz podnaslov Prosvjetiteljstvo kao masovna obmana (126-173) kao i daljnju razradu u T. W. Adorno (1991). Vidi također D. Strinati (1995), 1-79.

77 Vidi također: "In its attempts to manipulate the masses the ideology of the culture industry itself becomes as internally antagonistic as the very society which it aims to control. The ideology of the culture industry contains the antidote to its own lie" (ibid., 181). Također V. Biti (1987) i S. Buck-Morris (1977), 188-190 
obiteljima imali šansu da ne budu u potpunosti duhovno modeliran od strane postojećeg. ${ }^{78}$

Moramo još spomenuti da su čak i oni koji su se slagali sa Adornovom kritikom presudo-revolucionarnih aktivnosti iz tog razdoblja, ipak zamjerali nešto relativno slično kao i ti kritizirani studentski radikali. Tako je Habermas smatrao da kod Adorna izostaje političko-praktička dimenzija jer je u pogledu utopije postupao isto kao što su negativni teolozi postupali sa Bogom kada su tvrdili da mu se ne može, ne treba i ne smije pripisivati afirmativna određenja. ${ }^{79}$ Takvom, dosta raširenom čitanju Adorna idu u prilogu mnogo mjesta u njegovom opusu. Primjericu u jednom od zadnjih objavljenih radova stoji: "utopijski moment u mišljenju je tim jači što manje — jer i to je vid relapsa - objektivira sebe u utopiju jer tako sabotira vlastito ozbiljenje" ${ }^{80}$ Prateći takve misli, razvila se interpretacija koja drži da za Adorna nema ni trunke dobra, utopije ili pravog življenja u trenutno postojećem svijetu te da u takvim uvjetima ne možemo imati pouzdanu koncepciju pravog života.

Oni koji su školovani u dijalektičkoj teoriji, suzdržavaju se od pozitivnih slika ispravnog društva, njegovih građana, čak i onih koji bi trebalo da ga ostvare. Odvraćaju ih stari tragovi; u retrospektivnoj izmaglici, sve društvene utopije, još od Platona, povezuje sumorna sličnost sa onim protiv čega su bile izmišljene. Skok u budućnost, pravo preko današnjih uslova, završava u prošlosti. ${ }^{81}$

Premda Adornov opus obiluje ovakvim izjavama koje idu u prilog prvoj interpretaciji o izostanku kontinuiteta, ima i njegovih vrlo značajnih misli u prilog suprotnoj interpretaciji koja inzistira na kontinuitetu između trenutnog, krivog života i utopije. ${ }^{82}$ No, iako ovdje ne možemo ulaziti u detaljnije obrazlaganje, ključno je s obzirom na do sada izloženo zalagati se za drugu interpretaciju po kojoj je kod Adorna izrazito prisutno inzistiranje na određenom kontinuitetu između krivog života i utopije. "Samo oni koji bi utopiju mogli smjestiti u

78 "Kritika privilegija postaje privilegija: toliko je dijalektičan tijek svijeta" Adorno (1979), 55.

79 Relevantna mjesta u Habermasovom opusu navedi J. Gordon Finlayson (2012), 2-4. O širem odnosu Adorna i teologije v. Boer (2007), 391-443.

80 Adorno (1998), 292.

81 Usp. T. W. Adorno (2009), dodatak X.

$82 \mathrm{Za}$ pregled literature o tome v. J. Gordon Finlayson (2012), 5-6. 
slijepo tjelesno uživanje, koje je, zato što zadovoljava krajnju namjeru, lišeno svih namjera, mogu steći pouzdanu predstavu o istini”. ${ }^{33}$

Upravo tjelesnost sa svojim afektivnim apriorijem predstavlja zalog istinitosti utopije, tako da bi naglašavanje potpune različitosti postojećeg naspram onog što zahtijevamo prekinulo tanke veze s utopijom i preko kojih je jedino i možemo voditi ka ozbiljenju. Čak i u pitanju nesumnjivo negativnog stava prema misaonoj konkretizaciji utopije, ne smijemo zaboraviti da, kako je rekao vezano za nominalizam, toga se i generalno držeći “odnos genuino kritičke filozofije spram [nekog određenog aspekta filozofije] nije invarijantan, on se povijesno mijenja" ${ }^{84}$ Primjerice, već citirano Adornovo otvoreno afirmiranje nužnosti drukčijeg vrednovanje Hegelovog apsolutnog duha s obzirom na različite historijski trenutke, govori nam o tome da nominalizam nije bio izolirani slučaj. Varijantan stav spram različitih aspekata $u$ filozofiji, kao i šire, naspram više-manje svakog objekta promišljanja, uistinu je genuino kritički, odnosno dijalektički odnos:

Etičnost mišljenja ne leži ni u tvrdoglavom, niti u nadmoćnom držanju: ni u slijepom, niti u ispraznom istrajavanju; ni u atomiziranosti, niti u logičkoj dosljednosti. Dvosjekli metod, zbog kojeg je hegelovska fenomenologija među razumnim ljudima stekla reputaciju nečeg neizmjerno teškog, koji nalaže da se o nekoj pojavi govori kao takvoj - 'čisto promatranje', ali opet tako da se u svakom trenutku zadrži refleksija, odnos prema svijesti kao subjektu — izražava tu etičnost na najdirektniji način, ali i u svu dubinu njenih kontradikcija. Ali, koliko je samo teže danas usvojiti tu etičnost, kada više nije moguće uvjeriti se u identitet subjekta i objekta, što je ona krajnja pretpostavka na kojoj je Hegel još uvijek mogao prikrivati antagonističke zahtjeve promatranja i tumačenja. Od onih koji danas nešto misle, zahtijeva se ništa manje nego da u svakom trenutku budu u stvari i izvan nje — ponašanje barona Münchhausena, koji se izvukao iz močvare tako što je samog sebe povukao za kosu, postalo je obrazac za spoznaju koja ne želi biti samo potvrda ili spekulacija. A plaćeni filozofi nam i dalje prilaze i prigovaraju što nemamo čvrsto stanovište. ${ }^{85}$

83 Adorno (2009), $\mathbb{S} 37$ (prijevod adaptiran).

84 Adorno (1979) 336.

85 Adorno (2009), $\$ 46$ (prijevod adaptiran). 
Shodno tome, mislim da se može smatrati da i odnos spram misaone konkretizacije utopije također ne bi smio biti invarijantan, pogotovo ako imamo na umu urgentno stanje u kojem se naša planeta danas nalazi.

Za kraj, pokazat ćemo kako nam, kada promišljamo subverzivnu politiku utemljenu na ethosu realnog traženja nemogućeg, upravo Adorno, usprkos svojim apofatičkim tendencijama, može biti od značajne pomoći da s via negativa, karakterizirane modulacijom našeg slogana u Ne znamo što želimo, ali znamo što nećemo, prijeđemo na via positiva konkretnog djelovanja i određenih ciljeva.

\section{Dobra i loša nemogućnost}

Kad tako snažno afirmiramo utopijski moment u mišljenju, jedan od značajnih problema s kojim se tada susrećemo već je spomenuto neizbježno ulaženje takvog mišljenja u religijsku, odnosno fantastičnu domenu. Afektivni apriori, po samoj naravi stvari, pored želje za reduciranjem svake boli, izvor je i žudnje za besmrtnošću. Ako se želimo realno držati utopijskog, moramo iznaći jasan kriterij po kojem ćemo moći razlikovati želje koje treba dijalektički uzdignuti i uobličiti u određene ciljeve progresivnog djelovanja od onih koje ne bi trebali na takav način tretirati. Problem nije tako jednostavan kao što se isprva čini. Naime s većinom intuitivnih i elegantnih načina da ga riješimo, mi se, ako želimo ostati konzistentni, ne bi smjeli koristiti. Primjerice, ne smijemo se pozvati na tradicionalnu demarkaciju političke sfere prema kojoj bi mogli uzeti kao želje primjerene utopijskim ciljevima samo one koje se nalaze unutar toga, jer tako skrojene granice političkog, najčešće poprilično udaljene od ovlasti nad ključnom, ekonomskom sferom, simptomi su upravo postojećeg stanje koje želimo radikalno izmijeniti.

Ako bi uzeli kriterij tehnološke izvedivosti, to i dalje ne bi smjelo isključiti one želje koje su s obzirom na postojeće resurse i znanje trenutno nemoguće. Kriterij zapravo mora biti imanentan samoj afektivnoj sferi kako bi bili sigurni da smo izbjegli situaciju u kojoj bi zbog eksternih razloga odbacili želju koja je validni utopijski cilj, kao što je to učinio Spinoza po pitanju ravnopravnosti žena u svojoj političkoj misli. Određeno čitanje Adorna priskače nam tu u pomoć jer pruža putokaz za imanentno razlikovanje želja. Počnimo od jednog vrlo konkretnog slučaja: 
(...) kada je netko već "zauzet": kada je voljena osoba nepristupačna, ne zbog nekih unutrašnjih antagonizama ili inhibicija [...] već zato što se nalazi u vezi koja isključuje neku drugu. Apstraktni temporalni poredak zapravo igra ulogu koju bismo mogli pripisati hijerarhiji osjećanja. U toj zauzetosti, ako ostavimo po strani pitanje slobode izbora i odlučivanja, ima i nečeg krajnje nasumičnog, što izgleda da potpuno proturiječi zahtjevu za slobodom. Čak i u društvu izliječenom od anarhije robne proizvodnje, ili baš u njemu, jedva da bi bilo nekih pravila koja određuju način na koji se ljudi sreću. Kada bi bilo drugačije, onda bi takav aranžman bio izjednačen $s$ najneprihvatljivijim nasrtajem na slobodu. ${ }^{86}$

S obzirom na do sada određene uzuse utopijskog mišljenja, teško bismo mogli reći da u to ne bi mogla pripadati i želja za optimalnijim, razumnijim i manje nasumičnim uvjetima, pa makar to bilo i zaljubljivanja. Uz to, praktička implementacija tog cilja daleko je od neizvedive. Zamislimo primjerice neki program s kompleksnim algoritmom koji će na temelju raznih testova, obaveznih za cijelu populaciju, pokazati koji bi se sve pojedinci trebali susresti jer imaju velike šanse da bi se mogli smisleno povezati. To bi definitivno bio jedan efektni način da se donekle ublaži nasilnost potpuno nasumičnosti i neslobode kad je u pitanju neka tako bitna stvar za ljudski život. Ali ostvarenje ovakve želje stvorilo bi mnogo veću neslobodu od one koja postoji kao problem koji je trebao biti riješen. Kada bi se zadržali samo na ovom ne baš inovativnom računu, prema kojem ćemo prave utopijske zahtjeve prepoznati po tome da definitivno donose više slobode nego što oduzimaju, ne bismo baš imali previše koristi od Adornova uvida. Ali ako ga pratimo dalje, pored temporalnosti on se suočava sa još jednom dimenzijom koja nam se nadaje kao najintimnija drugost i nasumičnost koja priječi našu slobodu, a to je tjelesnost na čiji se značaj za Adorna kontinuirano vraćamo.

Sloboda koje se suprotstavlja nasumičnosti u ime samopostavljanja uma i autonomnog pripisivanja zakona, po kojima pristajemo živjeti, jedno je od centralnih filozofskih ekspresija naših žudnji, nadanja $i$ želja. Takva sloboda utkana je u sam fundament dijalektičke istine i predstavlja zalog utopijskog mišljenja, uz nju smo iznalazili svrhu i borili se za sve veću emancipaciju. Ali njena logika, premda je bila i ostala motor koji pokreće sva progresivna djelovanja, ne smije se

86 Adorno (2009), \$ 49 (prijevod adaptiran). 
slijediti najdalje moguće, bez ikakvih granica. ${ }^{87}$ Upravo tu zapravo dolazi ključna točka Adornove negativne dijalektike;

Iz dijalektike postojećeg ne može se isključiti ono što svijest doživljava kao stvarevito tuđe: negativno, prinudu i hetereonomiju [...]. Pomireno stanje ne bi s filozofijskim idealizmom anketiralo ono tuđe, nego bi svoju sreću imalo u tome da u omogućenoj blizini ostane tuđe i različito, s one strane heterogenoga i vlastitoga. ${ }^{88}$

Ovaj uvid od velikog je praktičkog značaja jer nam omogućuje da strogo pratimo utopijsko mišljenje traženja nemogućeg, a da nam pod to nemoguće ne dospiju razni suspektni ciljevi. Među te suspektne ciljeve možemo svrstati one koje bi se hegelijanski mogli označiti kao apstraktni, a takvi bi se ciljevi jedino i mogli pojaviti iz same Adornove koncepcije utopije ako je vjerovati interpretaciji koja nalaže da nema tragova pravog života u ovom krivom. ${ }^{89}$ Adorno nam nudi način kako da promišljamo razliku između granica na koje ne smijemo pristati čak ako i nema objektivnog načina da ih trenutno transcendiramo te onih granice koje ne bismo trebali prijeći, čak i ako postoje razni načini i razlozi da to učinimo. S tom dijalektikom granica doći ćemo do pojma slobode kao i patnje koji su uvjeti istinitosti na koje ćemo se onda moći osloniti pri traženju radikalne promjene postojećeg. Pritom nas ti isti pojmovi, nastali iz istina afektivnog aprioria, ne trebaju navesti na nerealna potraživanja za slobodom od svake prinude i boli, što će reći religijskog i tehnološkog snatrenja o besmrtnosti kojima je zajednički zazor ne od trenutno postojećeg, nego od života naprosto koji karakterizira njegova materijalnost.

87 Kao što smo vidjeli (v. dio teksta koji prate bilj. 54 i 55 ), Adorno snažno osuđuje tendenciju da se ide dalje bez obzira na prirodne limite, videći to prelaženje limita inficiranim od strane fetišizma robe, te smatra da će si društvo, oslobođeno od tog fetišizma, dopustiti da neke mogućnosti ostanu neiskorištene.

88 Adorno (1979), 166.

89 Protiv takve interpretacije snažno govori sljedeća Adornova tvrdnja (1991), 126: "The radicalism which promises itself everything by virtue of total change is abstract; for even within the changed totality the problems of the individual obstinately return again. Such radicalism loses ground as soon as its idea volatilizes into a chimera, dispensing every further effort toward improvement. Within itself, it then becomes an agent to sabotage something better. Excessive demand is a sublime form of sabotage." 
Vraćajući se za kraj još jednom na naš slogan, možemo reći da nam ovaj kriterij omogućava razlikovanje između dobre i loše nemogućnosti. Takva podjela je po uzoru na Hegelovu gdje se dobra beskonačnost "s pravom predstavila pomoću slike kruga" jer je beskonačna upravo u vraćanju samoj sebi, dok onu lošu predstavlja ravna liniji što se beskrajno proteže i ide sve dalje od same sebe. ${ }^{90} \mathrm{Na}$ tom tragu bismo i želje i nadanja afektivnog apriorija koje se vraćaju na vlastitu materijalnost umjesto da od nje bježe koliko god tehnički mogu daleko, mogli predstaviti kao dobre nemogućnosti. Adorno se nerijetko služio pojmom loše beskonačnosti, ${ }^{91}$ kao što je to uostalom činio i sa mnogim drugim filozofemima njemačkog idealizma. No, na jednom od mjesta gdje spominje lošu beskonačnost, opisat će upravo logiku naše intervencije u način razlikovanja utopijskih ciljeva, premda je u tom slučaju govorio o eseju kao formi:

Cjelina jest monada, a opet i nije, njezini elementi, budući da su pojmovne vrste, ukazuju dalje od specifičnog predmeta u kojem se okupljaju. Esej ih ne slijedi tamo gdje se legitimiraju izvan svoga specifičnog predmeta: inače bi dospio u lošu beskonačnost. On se toliko približava onome hic et nunc predmeta da se disocira u momente u kojima ima svoj život, umjesto da bude pukim predmetom. ${ }^{92}$

Spomenuti elementi se za naše razmatranje mogu shvatiti kao žudnje afektivnog apriorija, a specifični predmet izvan kojeg se ne bi trebali legitimirati, premda tome teže, naša je tjelesnost. No ovakvo čitanje izlaže se prigovoru: kako možemo ovom ulomku, koji se odnosi na esej, naprosto pridodati problematiku različitih vidova nemogućnosti? Što bi esej trebao biti, a što utopijski ciljevi, vrlo su različiti predmeti promišljanja, ono što vrijedi za jedno ne mora važiti za drugo. Međutim, Adorno opetovano pokazuje kako za njega esej nije puki prozni oblik, nego nešto daleko značajnije. ${ }^{93}$ Esej je od početka bio "kritička

90 G.W.F. Hegel (1989), Osnovne crte filozofije prava, 61-62.

91 Adorno (2009), \$ 105; v. ovdje bilj. 20.

92 T.W. Adorno (1985), Filozofsko-sociološki eseji o književnosti, 27.

93 O važnosti eseja za Adorna govori i činjenica da je i sam naslov prvog eseja u zbirci 1985. preveden kao "Esej o eseju" umjesto "Esej kao forma” (njem. Essay als Form). Za odnos Adorna, Benjamina, Blocha prema literarnom mediju v. predgovor Nadežde Čačinovič, "Adornovi eseji”, 5-15. Vidi također osobito T.R. Kray (2018), More dialectical than the dialectic: exemplarity in Theodor W. Adorno's The essay as form. 
forma par excellence; i to kao imanentna kritika duhovnih tvorevina". ${ }^{4}$ Razlog zašto esej ima tako privilegiranu poziciju u Adornovoj misli postat će jasan ako krenemo od samog izraza 'esej', koji znači ogled, ali i pokušaj. Upravo ovo drugo značenje daje iskaz o formi "u kojoj se utopija mišljenja da će mu uspjeti pogoditi u središte povezuje sa sviješću o vlastitoj pogrešivosti i privremenosti." ${ }^{95}$ Svijest, koja mu je upisana kako u naziv, tako i u formu, o toj svezi mišljenja utopije sa pogrešivošću i privremenošću nas samih koji je mislimo, omogućila je eseju da bude "dijalektičniji od dijalektike" i to upravo tamo gdje dijalektika kod Hegela "izlaže sebe samu." ${ }^{96}$ Premda se esej, karakteriziran svojom "pipajućom intencijom", ${ }^{77}$ i filozofija apsolutnog znanja čine kao dva suprotna pola, oni zapravo dijele istu ključnu zadaću - "izliječiti misao od njezine proizvoljnosti”. Dok esej "tu proizvoljnost vlastitim postupkom reflektira umjesto da je maskira kao neposrednost", Hegelova je filozofija "ostala opterećena inkonzekventnošću", jer, iako je svesrdno i silovito "kritizirala apstraktni vrhovni pojam, puki 'rezultat", ipak je u tom tonu i "po idealističkom običaju, govorila o dijalektičkoj metodi." 98

Esej se tako kod Adorna prometnuo u mjesto autorefleksije dijalektičkog, odnosno utopijskog mišljenja, tako da smjernice za kretanje u toj formi nisu nipošto nasumične, nego upravo suštinski povezane s problematikom koju ovdje razmatramo. Prilikom vrednovanja različitih zahtjeva afektivnog apriorija, slijediti taj eminentno esejski način kretanja, čini se pravim putem oslobađanja utopijskog mišljenja od balasta pretjerane spiritualnosti, čime se ono još jače i jasnije smješta u praktičku sferu.

94 Adorno (1985), 31.

95 Adorno, isto, 30.

96 Adorno, isto, 32.

97 Adorno, isto, 30.

98 Adorno, isto, 32. 


\section{LITERATURA}

Adorno, Theodor W. (1972), Tri studije o Hegelu, Sarajevo: Veselin Masleša (preveo Aleksa Buha).

Adorno, Theodor W. (1979), Negativna dijalektika, Beograd: Beogradski izdavačko-grafički zavod (preveli Nadežda Čačinovič-Puhovski i Žarko Puhovski).

Adorno, Theodor W. (1985), Filozofsko-sociološki eseji o književnosti, Zagreb: Školska knjiga, izbor i redaktura prijevoda Nadežda Čačinovič-Puhovski (preveli Nadežda Čačinovič-Puhovski, Borislav Mikulić i Hrvoje Glavač).

Adorno, Theodor W. (1991), The Culture Industry: selected essays on mass culture, London \& New York: Routledge (priredio Jay M. Bernstein).

Adorno, Theodor W. (1998), Critical models: Interventions and catchwords, New York: Columbia University Press (preveo Henry W. Pickford).

Adorno, Theodor W. i Marcuse, Herbert (1999), "Correspondence on the German Student Movement”, u: New Left Review, vol. 233, br.1 (priredila, prevela i uvod napisala Esther Leslie).

Adorno, Theodor W. (2002), "Who's afraid of the ivory tower?: A conversation with Theodor W. Adorno”, u: Monatshefte, vol. 94, br. 1 (priredio, preveo i uvod napisao Gerhard Richter).

Adorno, Theodor W. i Horkheimer, Max (1989), Dijalektika prosvjetiteljstva: filozofijski fragmenti, Sarajevo: Veselin Masleša (prevela Nadežda Čačinovič-Puhovski).

Adorno, Theodor W. (2009), Minima moralia: Refleksije iz oštećenog života, Anarhistička biblioteka (preveo Aleksa Golijanin); dostupno na https://anarhisticka-biblioteka.net/library/theodor-adorno-minima-moralia.

Amsler, Sarah S., Bringing hope to crisis: Rethinking the 'crisis of hope' in critical theory, dostupno na http://publications.aston.ac.uk/9146/1/Amsler Mining the_crisis_of_hope_in_contemporary critical_theory.pdf

Aristotel, Metafizika, Zagreb: Hrvatska sveučilišna naklada, 1992 (preveo Tomislav Ladan).

Ayers, Bill (2016a), Demand the Impossible! A Radical Manifesto, Chicago: Haymarket Books.

Ayers, Bill (2016b), "We Only Move Forward When We Demand the Impossible: An Interview With Bill Ayers", Truth Out, dostupno na https://truthout. org/articles/we-only-move-forward-when-we demand-the-imposible-an-interview-with-bill-ayers/

Balibar, Etienne (1994), Masses, classes, ideas: studies on politics before and after Marx, London \& New York: Routledge (preveo James Swenson).

Biti, Vladimir (1987), "Pogled na trivijalnu književnost danas”, u: Trivijalna književnost, ur. Svetlana Slapšak, Beograd: Studentski izdavački centar.

Bloch, Ernst (1988), The Utopian Function of Art and Literature: Selected Essays, 
Cambridge, Massachusetts: The MIT Press (preveli Jack Zipes i Frank Mecklenburg).

Bloch, Ernst (2000), The Spirit of Utopia, Stanford, California: Stanford University Press (preveo Anthony A. Nassae).

Boer, Roland (2007), Criticism of heaven - on marxism and theology, Leiden i Boston: Brill.

Boldyrev, Ivan (2014), Ernst Bloch and His Contemporaries: Locating Utopian Messianism, London: Bloomsbury Academic.

Buck-Moris, Susan. (1977), The origin of negative dialectics, London: The free press. Dolar, Mladen (2012), "Hegel and Freud”, u: e-flux journal 32, 2012, dostupno na https://www.e-flux.com/journal/34/6836o/hegel-and-freud/

Freyenhagen, Fabian (2014), "Adorno's Politics: Theory and Praxis in Germany's 1960s", u: Philosophy \& Social Criticism, vol. 40, br. 9.

Gordon Finlayson, James (2012), “On not being silent in the darkness: Adorno's singular apophaticism”, u: The Harvard Theological Review, vol. 105, br. 1.

Hegel, Georg Wilhelm Friedrich (1987), Fenomenologija duha, Zagreb: Naprijed (preveo Milan Kangrga).

Hegel, Georg Wilhelm Friedrich (1988), Lectures on the philosophy of religion-The lectures of 1827, Berkeley: University of California Press (preveli R. F. Brown, P. C. Hodgson i J. M. Stewart).

Hegel, Georg Wilhelm Friedrich (1989), Osnovne crte filozofije prava, Sarajevo: Veselin Masleša (preveo Danko Grlić).

Heinrich, Michael (2012), An introduction to the three volumes of Karl Marx's Capital, New York: Monthly Review Press (preveo Alexander Locascio).

Honneth, Axel (2008), Reification: a new look at an old idea, Oxford: Oxford University Press.

Jameson, Fredric (2009), Valences of the dialectic, London: Verso.

Järvensivu, Paavo i Toivanen, Tero i Vadén, Tere i Lähde, Ville i Majava, Antii i Eronen, Jussi T. (2019), Global Sustainable Development Report 2019 drafted by the Group of independent scientists, dostupno na https://bios.fi/ bios-governance_of_economic_transition.pdf

John, Yohan J. i Bullock, Daniel i Zikopoulos, Basilis i Barbas Helen (2013), "Anatomy and computational modeling of networks underlying cognitive-emotional interaction", u: frontiers in Human Neuroscience, vol. 7, dostupno na https://www.researchgate.net/publication/236129681_Anatomy_and_computational_modeling_of_networks_underlying_cognitive-emotional_interaction Jütten, Timo (2019), Adorno on hope, u: Philosophy and Social Criticism, vol. 45 , br. 3 .

Kant, Immanuel (1998), Critique of Pure Reason, Cambridge: Cambridge University Press (preveli Paul Guyer i Allen W. Wood). 
Kray, Thorn R. (2018), "More dialectical than the dialectic: exemplarity in Theodor W. Adorno's The essay as form”, u: Thesis Eleven, vol. 144, br. 1.

Levitas, Ruth (2008), "Be realistic: demand the impossible”, u: New Formations br. 63 .

Malabou, Catherine (2016), Ontologija nezgode-esej o razaralačkoj plastičnosti, Zagreb: Kulturtreger (preveo Marko Gregorić).

Marcuse, Herbert (1968), Čovjek jedne dimenzije, Sarajevo: Veselin Masleša (prevela Branka Brujić).

Marcuse, Herbert (1970), Five lectures - Psychoanalysis, Politics and Utopia, London: Allen Lane The Penguin Press (preveli Jeremy J. Shapiro i Shierry M. Weber).

Marx, Karl (1974), Kapital. Kritika političke ekonomije (prvi tom). Proces proizvodnje kapitala, Beograd: Prosveta (preveli Moša Pijade i Rodoljub Čolaković).

Marx, Karl (1977), Temelji slobode - Osnovi kritike političke ekonomije (Grundrisse), Zagreb: Naprijed (preveli Branko Petrović, Gajo Petrović i Moša Pijade). Schick, Kate (2009), 'To lend a voice for suffering is a condition for all truth': Adorno and International Political Thought, u: Journal of International Political Theory, vol. 5, br. 2.

Spinoza, Benedikt de (2006), Politička rasprava, Zagreb: Demetra (preveo Ozren Žunec).

Stolze, Ted (2012), Hegel or Spinoza: Substance, Subject, and Critical Marxism, $\mathrm{u}$ : Crisis and critique, br. 3.

Strinati, Dominic (1995), An Introduction to Theories of Popular Culture, London \& New York: Routledge.

Van den Berg, Axel (1980), “Critical theory: Is there still hope?”, u: American Journal of Sociology, vol. 86, br. 3.

Vighi, Fabio (2012), Critical theory and film: rethinking ideology in cinema, London: Bloomsbury Continuum.

Watzlawick, Paul (1978), The Language of Change: Elements of Therapeutic Communication, New York: Basic Books.

Winters, Joseph (2014), "Theodor Adorno and the unhopeless work of the negative”, u: Journal of Cultural and Religious Theory, vol. 14, br. 1.

Žižek, Slavoj (2013), Demanding the Impossible, ur. Yong-june Park, Cambridge: Polity Press.

Žižek, Slavoj (2004), Organs without Bodies: Deleuze and Consequences, London \& New York: Routledge. 


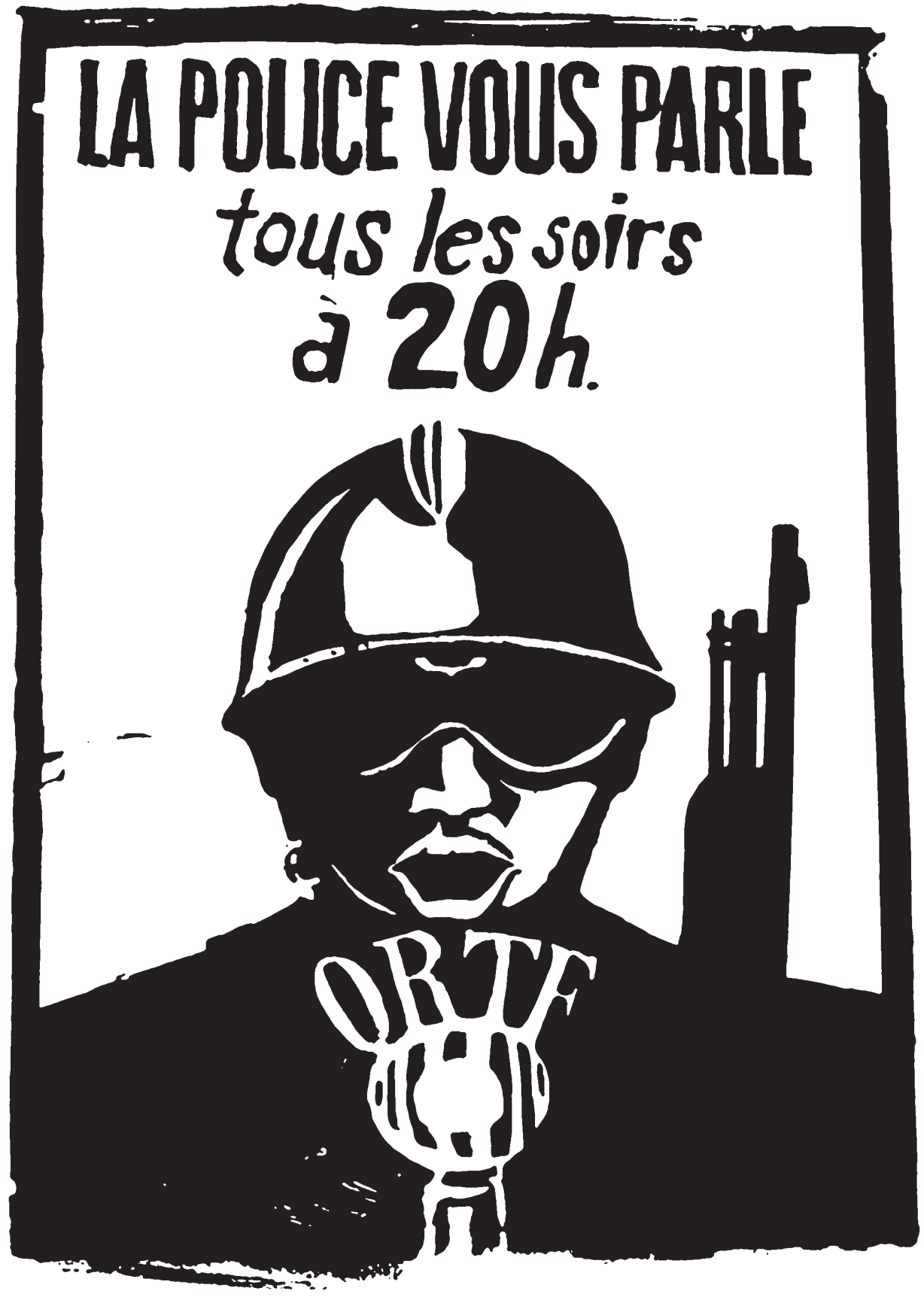

